\title{
Impact of vehicular emissions on the formation of fine particles in the Sao Paulo Metropolitan Area: a numerical study with the WRF-Chem model
}

\author{
A Vara-Vela ${ }^{1}$, M. F. Andrade ${ }^{1}$, P. Kumar ${ }^{2,3}$, R. Y. Ynoue ${ }^{1}$, and A. G. Muñoz ${ }^{4,5}$ \\ ${ }^{1}$ Department of Atmospheric Sciences, Institute of Astronomy, Geophysics and Atmospheric Sciences, \\ University of Sao Paulo, Sao Paulo, Brazil \\ ${ }^{2}$ Department of Civil and Environmental Engineering, Faculty of Engineering and Physical Sciences (FEPS), \\ University of Surrey, Guilford GU2 7XH, UK \\ ${ }^{3}$ Environmental Flow (EnFlo) Research Centre, Faculty of Engineering and Physical Sciences, \\ University of Surrey, Guildford GU2 7XH, UK \\ ${ }^{4}$ International Research Institute for Climate and Society (IRI), Columbia University, Palisades, \\ NY 10964-1000, USA \\ ${ }^{5}$ Centro de Modelado Científico (CMC), Universidad del Zulia, Maracaibo, Venezuela \\ Correspondence to: A. Vara-Vela (angel.vela@iag.usp.br)
}

Received: 23 January 2015 - Published in Atmos. Chem. Phys. Discuss.: 20 May 2015

Revised: 3 December 2015 - Accepted: 8 January 2016 - Published: 25 January 2016

\begin{abstract}
The objective of this work is to evaluate the impact of vehicular emissions on the formation of fine particles $\left(\mathrm{PM}_{2.5} ; \leq 2.5 \mu \mathrm{m}\right.$ in diameter) in the Sao Paulo Metropolitan Area (SPMA) in Brazil, where ethanol is used intensively as a fuel in road vehicles. The Weather Research and Forecasting with Chemistry (WRF-Chem) model, which simulates feedbacks between meteorological variables and chemical species, is used as a photochemical modelling tool to describe the physico-chemical processes leading to the evolution of number and mass size distribution of particles through gas-to-particle conversion. A vehicular emission model based on statistical information of vehicular activity is applied to simulate vehicular emissions over the studied area. The simulation has been performed for a 1-month period (7 August-6 September 2012) to cover the availability of experimental data from the NUANCE-SPS (Narrowing the Uncertainties on Aerosol and Climate Changes in Sao Paulo State) project that aims to characterize emissions of atmospheric aerosols in the SPMA. The availability of experimental measurements of atmospheric aerosols and the application of the WRF-Chem model made it possible to represent some of the most important properties of fine particles in the SPMA such as the mass size distribution and chemical composition, besides allowing us to evaluate its formation poten-
\end{abstract}

tial through the gas-to-particle conversion processes. Results show that the emission of primary gases, mostly from vehicles, led to a production of secondary particles between 20 and $30 \%$ in relation to the total mass concentration of $\mathrm{PM}_{2.5}$ in the downtown SPMA. Each of $\mathrm{PM}_{2.5}$ and primary natural aerosol (dust and sea salt) contributed with $40-50 \%$ of the total $\mathrm{PM}_{10}$ (i.e. those $\leq 10 \mu \mathrm{m}$ in diameter) concentration. Over $40 \%$ of the formation of fine particles, by mass, was due to the emission of hydrocarbons, mainly aromatics. Furthermore, an increase in the number of small particles impaired the ultraviolet radiation and induced a decrease in ozone formation. The ground-level $\mathrm{O}_{3}$ concentration decreased by about $2 \%$ when the aerosol-radiation feedback is taken into account.

\section{Introduction}

The Sao Paulo Metropolitan Area (SPMA), in the southeast region of Brazil, is considered a megalopolis comprised of Sao Paulo city and more than 38 municipalities. One of the main concern in the SPMA is the occurrence of violations of air quality standards for ozone and fine particles at different air quality stations from the Sao Paulo Environmental 
Agency (CETESB). The air pollutant emissions in the SPMA are related to the burning of the following fuels: ethanol, gasohol (gasoline with $25 \%$ ethanol), and diesel. Recent work of Carvalho et al. (2015) reported a substantial increase in number of road vehicles from 1 million in 2000 to almost 7 million in 2014, together with an overview of the pollutants concentration, fuel use in the SPMA and the relationship between the emissions and the improvement in the air quality in past years.

They constitute the main cause of impairment to air quality in the SPMA, but the number of air quality standard violations has decreased for almost all pollutants with the exception of $\mathrm{PM}_{2.5}$ and $\mathrm{O}_{3}$. Both these pollutants are impacted by the vehicular emissions and have experienced an increase in the number of violations of local air quality standards as discussed in detail by Carvalho et al. (2015). Pérez-Martínez et al. (2015) have analysed the monthly mean values for the regulated pollutants from 2000 to 2013 for the air quality stations in the SPMA. They found a decrease in the average concentration of $\mathrm{NO}_{x}, \mathrm{CO}$, and $\mathrm{PM}_{10}$ by $0.65,0.37$, and $0.71 \%$ month $^{-1}$, respectively, although the sales of the fuels (gasoline, ethanol, and diesel) had increased by $0.26,1.96$, and $0.38 \%$ month $^{-1}$, respectively.

A recent report from CETESB (CETESB, 2013) highlighted that, in 2012, the vehicles contributed with about $40 \%$ of the total $\mathrm{PM}_{10}$ mass concentrations through direct emissions. If we consider the secondary aerosols, which were about $25 \%$ of $\mathrm{PM}_{10}$ as estimated by CETESB (2013), these were mainly found to be formed by chemical reactions between gases released from exhaust of vehicles.

The implementation of the Program for the Control of Vehicular Emission (PROCONVE) established by the Brazilian Government in the 80's, enforcing measures such as use of catalytic converters and ethanol as additive to gasoline in substitution of tetraethyllead, led to a decrease in emissions of $\mathrm{CO}$ and VOCs and hence their ambient concentration. Although the emissions have been controlled by regulations, the number of vehicles has increased substantially and faster than the replacement of the old vehicles by the new ones (Pérez-Martínez et al., 2014). According to CETESB (2013), the road vehicles contributed up to about 97,87 , and $80 \%$ of CO, VOCs, and $\mathrm{NO}_{x}$ emissions in 2012, respectively, being most of $\mathrm{NO}_{x}$ associated to diesel combustion and most of CO and VOCs from gasohol and ethanol combustion. Receptor modelling studies applied to six capital cities in Brazil (Andrade et al., 2012) showed that only $13 \%$ of $\mathrm{PM}_{2.5}$ in the SPMA is associated to the emission by the industrial processes (oil burning and secondary aerosols).

To date, many studies assessing the impact of biofuels on the air quality have been performed in Brazil. For example, Anderson (2009) conducted a review concerning the use of ethanol fuel in Brazil. His work highlighted that the atmospheric concentrations of acetaldehyde and ethanol are much higher in Brazil in comparison with the other areas of the world. Costa and Sodré (2010) showed that exhaust emissions of hydrous ethanol reduced $\mathrm{CO}$ and Hydrocarbons (HC), but increased $\mathrm{CO}_{2}$ and $\mathrm{NO}_{x}$ levels.

A number of past studies has shown the significant participation of the carbonaceous compounds in the concentration of fine particles in the SPMA (Albuquerque et al., 2011; Miranda and Andrade, 2005; Ynoue and Andrade, 2004; Castanho and Artaxo, 2001). Studies conducted on ambient air pollution in the SPMA have also shown that BC explains $21 \%$ of mass concentrations of fine particles $\left(\mathrm{PM}_{2.5}\right.$; $\leq 2.5 \mu \mathrm{m}$ in diameter) compared with $40 \%$ of organic carbon (OC), $20 \%$ of sulfates, and $12 \%$ of soil dust (Andrade et al., 2012). Most of the observed ambient $\mathrm{PM}_{2.5}$ mass concentration usually originates from precursors gases such as sulphur dioxide $\left(\mathrm{SO}_{2}\right)$, ammonia $\left(\mathrm{NH}_{3}\right)$, nitrogen oxides $\left(\mathrm{NO}_{x}\right)$, and volatile organic compounds (VOCs) as well as through the physico-chemical processes such as the oxidation of lowvolatile hydrocarbons noted above transferring to the condensed phase (McMurry et al., 2004; Heal et al., 2012). Since these processes are often photo-chemically driven, the resultant aerosol usually falls into the category of secondary photochemical pollutant (Jenkin and Clemitshaw, 2000). Oxidation of VOCs can produce species of sufficiently low vapour pressure to be condensable, leading to the formation of secondary organic aerosol (SOA) (Kroll and Seinfeld, 2008). Fine particles in SPMA have a great participation on its composition of SOA, formed from the emissions of VOCs, which have the same origin of the primary compounds involved in the formation of ozone, from the burning of fuels. The participation of the biogenic emission is considered to be small in the formation of particles in the metropolitan area of the city according to previous studies of Martins et al. (2006).

The impact of the fine particles has been discussed in previous works, with evaluation of the scattering and absorbing effects of the aerosol (e.g. Li et al., 2005; Real and Sartelet, 2011). Vehicular emissions of particulate matter (PM) in the SPMA have a high percentage of BC (Brito et al., 2013), which after emitted to the atmosphere can enhance the absorption coefficient and thus the attenuation rates.

One of the most important aspects of this work is the quantitative analysis of the formation of $\mathrm{PM}_{2.5}$ and ozone $\left(\mathrm{O}_{3}\right)$ in the SPMA. Photolysis of $\mathrm{O}_{3}$ by ultraviolet light in the presence of water vapour is the main source of hydroxyl radical $(\mathrm{OH})$, the most important radical in the atmosphere in terms of reactivity (Monks, 2005). At the same time, $\mathrm{OH}$ levels in the atmosphere directly determine the oxidation rate of the precursors of secondary aerosols. Oxidation products of VOCs and semi-VOCs by $\mathrm{OH}$ are the most important precursors of SOA (Li et al., 2011a). Although VOCs and $\mathrm{NO}_{x}$ are precursors of both $\mathrm{O}_{3}$ and a fraction of atmospheric $\mathrm{PM}\left(\mathrm{NO}_{3}^{-}\right.$and secondary organics) while they influence indirectly the formation of the rest of the secondary $\mathrm{PM}$ components like $\mathrm{SO}_{4}^{=}$, their control strategies that are optimal for $\mathrm{O}_{3}$ controls may even increase $\mathrm{PM}_{2.5}$ concentrations (McMurry et al., 2004). Such an analysis is important to evaluate the contribution of the vehicular fleet us- 
Table 1. Description of aerosol sampling campaigns performed at IAG-USP.

\begin{tabular}{llll}
\hline Parameter & Sampling frequency & Period of sampling & Sampling device \\
\hline $\begin{array}{l}\text { Aerosol mass size } \\
\text { distribution }\end{array}$ & $24 \mathrm{~h}$ & July-September & $\begin{array}{l}\text { MOUDI } \\
\text { impactor }\end{array}$ \\
$\begin{array}{l}\mathrm{PM}_{2.5} \text { and } \mathrm{PM}_{10} \\
\text { concentration }\end{array}$ & $12 \mathrm{~h}$ & July-September & $\begin{array}{l}\text { Dichotomous } \\
\text { sampler }\end{array}$ \\
$\begin{array}{l}\text { OC and EC } \\
\text { concentration }\end{array}$ & $12 \mathrm{~h}$ & August-September & $\begin{array}{l}\text { Sunset OC-EC } \\
\text { analyser }\end{array}$ \\
\hline
\end{tabular}

ing different kind of fuels to the concentration of fine particles. In this sense, a numerical study with an adequate physical approach, representing particles in the modelling system, is important to understand the formation of secondary aerosols from primary emission of gases in a metropolitan area where the composition of fuel in vehicular fleet has changed significantly over the past years. Therefore, the goal of the present study is to evaluate the impact of vehicular emissions on the formation of fine particles in the SPMA, focusing especially on the potential formation of secondary particles from the primary emission of gases coming from on-road vehicles. The impact of aerosol particles on the ozone photochemistry is also examined by means of numerical simulations. Measurements were performed to provide input data to evaluate the modelling performance and estimate the vehicular emission factors. Aerosol measurements were taken from field campaigns that were carried out as part of the Narrowing the Uncertainties on Aerosol and Climate Changes in Sao Paulo State (NUANCESPS) project (http://nuance-lapat.iag.usp.br/). These campaigns took place between July and September 2012. An online-coupled meteorology and chemistry model, i.e. the Weather Research and Forecasting with Chemistry (WRFChem) model, has been used to characterize and describe the physico-chemical processes involved in both the formation and growth of new particles over the SPMA in southern Brazil. The details of the experimental campaigns, WRFChem model and emissions are described in Sect. 2. Results from modelling experiments and comparison with measurements are presented in Sect. 3. Finally, the summary and conclusions are given in Sect. 4.

\section{Methodology}

\subsection{Observational data sets}

The study period starting from 7 August until 6 September 2012 was selected for comparison with the modelled results (Sect. 2.2) due to the availability of experimental data from the NUANCE-SPS project. The aim of NUANCESPS was to evaluate the impact of emissions in the SPMA on the air quality and changing climatic conditions, and feedback mechanisms between climatic perturbations pro- duced by both primary and secondary emissions and urban atmospheric processes. Aerosol observation data sets used in this work were collected using a Dichotomous sampler (Wedding et al., 1980) and a Micro-Orifice Uniform Deposit Impactor (MOUDI, model 100; MSP Corporation; Marple et al., 1986). The MOUDI impactor collected particles in 10 size classes with nominal $50 \%$ cut-off diameters: 10, 5.6, $3.2,1.8,1.0,0.56,0.32,0.18,0.1$, and $0.06 \mu \mathrm{m}$. Particles smaller than $0.06 \mu \mathrm{m}$ were collected in a subsequent stage or after-filter. The samples collected with the MOUDI impactor were deposited on a polycarbonate membrane filter with $0.4 \mu \mathrm{m}$ porous and for the Dichotomous sampler the substrate was a teflon membrane filter with $2 \mu \mathrm{m}$ porous. The after-filter in the MOUDI impactor is a $33 \mathrm{~mm}$ teflon membrane filter, which was not submitted to the reflectance analysis. The collected membrane filters sampled with the Dichotomous and MOUDI samplers were analysed to the identification of trace elements of mass through X-ray diffraction analysis, mass concentration through gravimetric analysis, and black and organic carbon through reflectance and thermo analysis using a thermal-optical transmittance (TOT) (Sunset Laboratory Inc.; Birch and Cary, 1996). Ion concentrations were evaluated through the ion chromatography analysis of the soluble material collected on the membrane filters (sulphate, nitrate, ammonium, sodium, and chloride). All these samplings were performed on the roof of the main building of the Institute of Astronomy, Geophysics and Atmospheric Sciences of the University of Sao Paulo (IAGUSP) (hereafter also referred as IAG-USP measurement site or simply IAG-USP), which is inside a small green-park (approximately $7.4 \mathrm{~km}^{2}$ ), with local traffic during the day and surrounded by major roads with intense traffic by light and heavy-duty vehicles (Nogueira et al., 2014). Table 1 lists the aerosol instrumentation deployed roughly at the IAGUSP measurement site. In addition, ambient data from the CETESB's air quality monitoring network and the IAGUSP's climatological station (hereafter also referred as AFIAG) were also considered for evaluation of numerical simulations. The locations of measurement sites are depicted in Fig. 1 whereas geographic coordinates, urban-suburban classification, and the list of pollutants and meteorological parameters monitored at each site is available in Table 2 . 


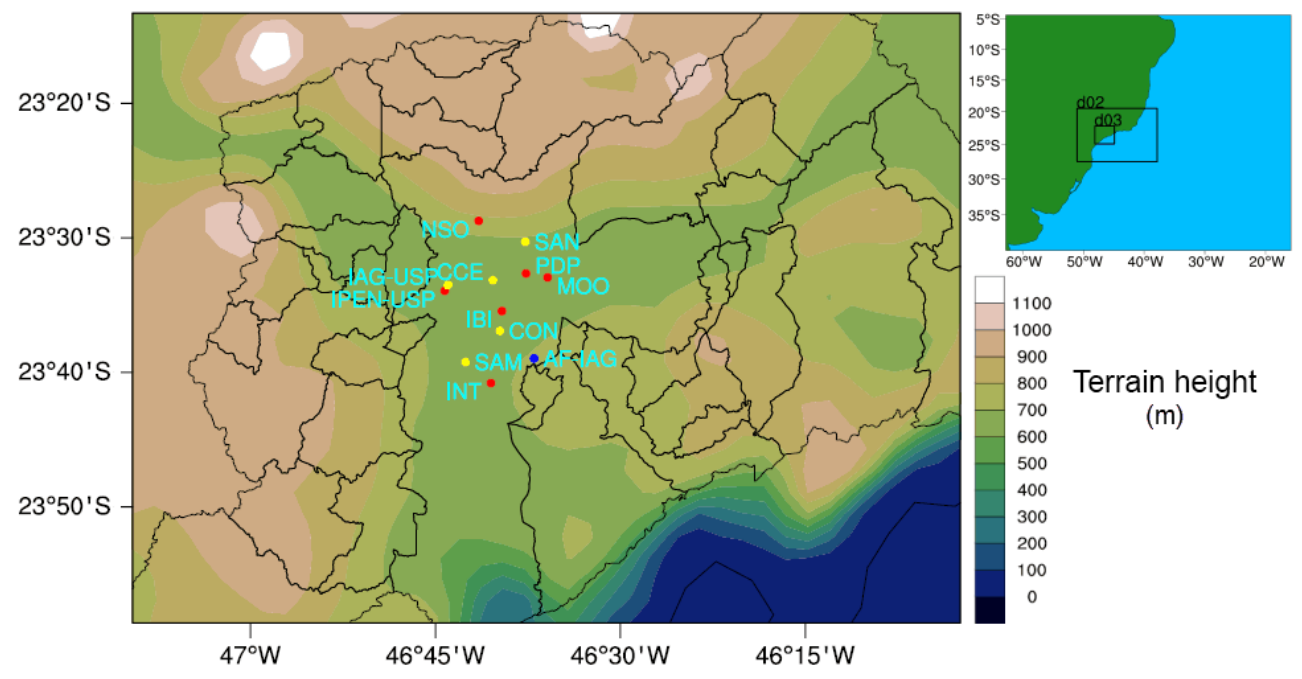

Figure 1. Downtown area of the $3 \mathrm{~km}$ modelling domain (d03) showing the locations of measurement sites and WRF topography in the vicinity of the SPMA. Red dots represent sites with information on $\mathrm{O}_{3}$ and PM. Yellow dots represent only sites with information on PM. Blue dot represents the location of the IAG-USP's climatological station.

Table 2. Description of measurement sites.

\begin{tabular}{llllll}
\hline Site & Initials & Latitude & Longitude & Classification & Measured species \\
\hline Nossa S. do O & NSO & -23.4796 & -46.6916 & Urban & $\mathrm{PM}_{10}, \mathrm{O}_{3}$ \\
Santana & SAN & -23.5055 & -46.6285 & Urban & $\mathrm{PM}_{10}$ \\
Parque D. Pedro & PDP & -23.5448 & -46.6276 & Urban & $\mathrm{PM}_{10}, \mathrm{O}_{3}$ \\
Mooca & MOO & -23.5497 & -46.5984 & Urban & $\mathrm{PM}_{10}, \mathrm{O}_{3}$ \\
Cerqueira Cesar & CCE & -23.5531 & -46.6723 & Urban & $\mathrm{PM}_{10}$ \\
IAG-USP & IAG-USP & -23.5590 & -46.7330 & Suburban & $\mathrm{PM}_{10}, \mathrm{PM}_{2.5}, \mathrm{OC}, \mathrm{EC}$, \\
& & & & & aerosol mass size distrib. $^{\mathrm{a}}$ \\
IPEN-USP & IPEN-USP & -23.5662 & -46.7374 & Suburban & $\mathrm{PM}_{2.5}, \mathrm{O}_{3}, \mathrm{NO}_{x}, \mathrm{CO}$ \\
Ibirapuera & IBI & -23.5914 & -46.6602 & Suburban & $\mathrm{PM}_{10}, \mathrm{O}_{3}, \mathrm{NO}_{x}, \mathrm{CO}$ \\
Congonhas & CON & -23.6159 & -46.6630 & Urban & $\mathrm{PM}_{10}, \mathrm{PM}_{2.5}$ \\
AF-IAG & AF-IAG & -23.6500 & -46.6167 & Suburban & $T, \mathrm{RH}_{2} \mathrm{WS}, \mathrm{WD}^{\mathrm{b}}$ \\
Santo Amaro & SAM & -23.6545 & -46.7095 & Urban & $\mathrm{PM}_{10}$ \\
Interlagos & INT & -23.6805 & -46.6750 & Urban & $\mathrm{PM}_{10}, \mathrm{O}_{3}, T, \mathrm{RH}, \mathrm{WS}, \mathrm{WD}$ \\
\hline
\end{tabular}

a Includes $\mathrm{SO}_{4}^{2-}, \mathrm{NO}_{3}^{-}, \mathrm{NH}_{4}^{+}, \mathrm{Na}^{+}, \mathrm{Cl}^{-}$and $\mathrm{PM}_{10}{ }^{\mathrm{b}} T, \mathrm{RH}, \mathrm{WS}$, and WD denote temperature, relative humidity, wind speed and wind direction, respectively.

\subsection{WRF-Chem model}

The WRF-Chem model is a fully coupled online meteorological and chemical transport model (Grell et al., 2005), supported by National Center for Atmospheric Research (NCAR) of the USA and several other research institutions around the world. This model is a system of two key components. The WRF-Chem meteorological component, the Weather Research and Forecasting (WRF), is a system configured for both research and operational applications. The dynamical core used in this study is the Advanced Research WRF (ARW). Model's equations into ARW are solved to non-hydrostatic conditions on a fully compressible atmosphere. Further details on the modelling system can be found on the WRF model website (http://www.wrf-model.org). On the other hand, the WRF-Chem chemical component treats chemical processes such as dry deposition, gas-phase chemistry, photolysis rates, and aerosols chemistry. A detailed description of the WRF-Chem model can be found on its website (http://ruc.noaa.gov/wrf/WG11). Since both meteorological and chemical components are fully coupled, the transport of all chemical species is on-line. The gas-phase chemistry and aerosol modules employed in this study are the Regional Acid Deposition Model, version 2 (RADM2) (Chang et al., 1989) and the Modal Aerosol Dynamics Model for Europe - Secondary Organic Aerosol Model (MADE-SORGAM) (Ackermann et al., 1998; Schell et al., 2001), respectively. The inorganic species included in the RADM2 mechanism 
are 14 stable species, 4 reactive intermediates, and 3 abundant stable species (oxygen, nitrogen, and water). Atmospheric organic chemistry is represented by 26 stable species and 16 peroxy radicals. The RADM 2 mechanism represents organic chemistry through a reactivity aggregated molecular approach (Middleton et al., 1990). Similar organic compounds are grouped together in a limited number of model groups through the use of reactivity weighting. The aggregation factors for the most emitted VOCs are given in Middleton et al. (1990).

On the other hand, the most important process for the formation of secondary aerosol particles is the homogeneous nucleation in the sulfuric acid-water system. It is parameterized in MADE, following the method of Kulmala et al. (1998). Aerosol growth by condensation occurs in two steps: the production of condensable material (vapour) by the reaction of chemical precursors, and the condensation and evaporation of ambient volatile species on aerosols. The inorganic chemistry system, based on the Model for an Aerosol Reacting System (MARS) (Saxena et al., 1986) and its modifications by Binkowski and Shankar (1995), calculates the chemical composition of a sulphate-nitrate-ammoniumwater aerosol according to equilibrium thermodynamics. The organic aerosol chemistry is based on the SORGAM, which assumes that SOA compounds interact and form a quasiideal solution (Grell et al., 2005). The SOA formation in SORGAM follows the two-product approach (Odum et al., 1996) where the oxidation of hydrocarbons produces two types of modelled semivolatile compounds that are partitioned between the gas and particle phases after considering the absorptive partitioning theory (Pankow, 1994a, b). The primary organic aerosol (POA) in MADE is calculated from the primary anthropogenic emission of OC. Then, one may calculate the predicted OC concentration from the sum of both SOA and POA. The concurrent organic matter (OM) can be obtained from the OC concentration by application of a conversion factor. Brown et al. (2013) showed that the average OM : OC ratio was 1.54 (with a standard deviation of 0.2 ) for sites with low amount of secondary aerosol formation. It is important to note that this ratio can change from one place to another. In areas impacted by biomass burning the ratio can be higher. Gorin et al. (2006) assumed a ratio of 1.6 for the conversion from OC to OM over an area that experiences a significant wood smoke influence.

\section{Model configuration}

WRF-Chem version 3.6 was configured with three nested grid cells: coarse $(75 \mathrm{~km})$, intermediate $(15 \mathrm{~km})$, and fine $(3 \mathrm{~km})$. The coarse grid cell covered a big region of Brazil and also of the Atlantic Ocean. The intermediate grid covered southeast Brazil while the fine grid cell covered barely the SPMA and metropolitan areas nearest to it. Figure 1 shows the arrangement of measurement sites and topography in the downtown area of the $3 \mathrm{~km}$ modelling domain. The
Table 3. Selected WRF-Chem configuration options.

\begin{tabular}{ll}
\hline Atmospheric process & WRF-Chem option \\
\hline Longwave radiation & RRTM \\
Shortwave radiation & Goddard \\
Surface layer & Monin-Obukhov \\
Land surface & Noah \\
Boundary layer & YSU \\
Cumulus clouds* & Grell 3D \\
Cloud microphysics & Lin \\
Gas-phase chemistry & RADM2 \\
Aerosol chemistry & MADE/SORGAM \\
Photolysis & Fast-J \\
\hline
\end{tabular}

* Outer domains only.

initial and boundary meteorological conditions are from the National Center for Environmental Prediction's Final Operational Global Analysis with $1^{\circ}$ of grid spacing, 26 vertical levels and are available every 6 hours: 00:00, 06:00, 12:00, and 18:00 UTC (http://rda.ucar.edu/datasets/ds083.2/). The initial and boundary chemical conditions for representing gases and aerosols background concentration were obtained from the Model for Ozone and Related chemical Tracers, version 4 (MOZART-4; Emmons et al., 2010). This model was driven by meteorological inputs from the Goddard Earth Observing System Model, version 5 at a horizontal resolution of $1.9^{\circ} \times 2.5^{\circ}, 56$ vertical levels that are also available every 6 hours. Table 3 lists the WRF-Chem configuration options employed by this study.

WRF-Chem simulation with coupled primary aerosol (dust, sea salt and anthropogenic) and gas (biogenic and anthropogenic) emission modules, together with the direct effect of aerosol particles turned on, is performed as the control simulation in order to evaluate the model performance (hereafter referred to as Case_0). For secondary aerosols, a simulation scenario (Case_1) with biogenic and anthropogenic gases emission is performed to evaluate its formation potential. An additional simulation (Case_2) is also performed to evaluate the impact of aerosols on ozone photochemistry. Notation and description of simulations are listed in Table 4. The first 7 days of each simulation were not analysed and used for model spin-up.

\subsection{Emissions}

\subsubsection{Anthropogenic emissions}

Because on-road vehicles are the most important sources of air pollution in southeast Brazil's metropolitan areas, particularly in SPMA where, according to CETESB, more than $80 \%$ of pollutant emissions are generated by vehicular emissions; the anthropogenic emissions of trace gases and particles in both 3 and $15 \mathrm{~km}$ modelling domains were considered to include emissions only coming from on-road vehicles 
Table 4. Description of WRF-Chem simulations.

\begin{tabular}{ll}
\hline Label & Description \\
\hline Case_0 & Emission of gases \\
(Baseline simulation) & Emission of aerosols \\
& Aerosol-radiation feedback turned on \\
Case_1 & Emission of gases \\
& No emission of aerosols \\
& Aerosol-radiation feedback turned on \\
Emission of gases \\
Emission of aerosols \\
& Aerosol-radiation feedback turned off \\
\hline
\end{tabular}

through the use of a vehicular emission model developed by the IAG-USP's Laboratory of Atmospheric Processes (LAPAt). Basically, this model considers the number of vehicles, vehicular emission factors, and average driving kilometres for vehicle per day as basic parameters for the calculation of exhaust emissions considering different vehicle types (light-duty vehicles, heavy-duty vehicles, and motorcycles) and different fuel types (ethanol, gasohol, combination of any proportion of gasohol and ethanol, and diesel) according to CETESB (2012). The details of this model are available in Andrade et al. (2015). In the case of VOCs, there are another two relevant emissions (fuel transfer and evaporative processes) associated with the vehicles, besides the exhaust

emissions. Because of the complexities in the spatial representation due to numerous factors such as emissions at service stations, such emission sources are assumed to be emitted by exhaust of vehicles for the sake of simplicity. The vehicular fleet and intensity of use data sets are provided by the National Department of Traffic (DENATRAN) and the Sao Paulo Transporte (SPTrans), respectively. Emission factors for road vehicles for most pollutants were considered from previous studies performed inside road tunnels (i.e. Janio Quadros, referred as JQ tunnel, and the tunnel 3 of the Rodoanel Mario Covas that is referred hereafter as RA tunnel) located within the SPMA (Pérez-Martínez et al., 2014; Nogueira et al., 2014). However, emission factors for VOCs are considered from dynamometer protocols (CETESB, 2010). VOCs and PM speciation profiles used by gas-phase and aerosol chemical modules were also obtained from NUANCE-SPS experimental campaigns performed in 2011 (tunnel measurements) and 2012 (ambient data). It is important to note that due to the lack of information on vehicular emission factors and intensity of use for most of the other metropolitan areas inside both modelling domains (e.g. the Campinas Metropolitan Area, which is shown by the second largest grey stain in Fig. 2), the calculation of vehicular emissions for these urban areas was carried out on the basis of the parameters found for the SPMA. The number of vehicles in any modelling domain is calculated from the sum of the number of vehicles in each one of the main urban areas inside the modelling domain in question.

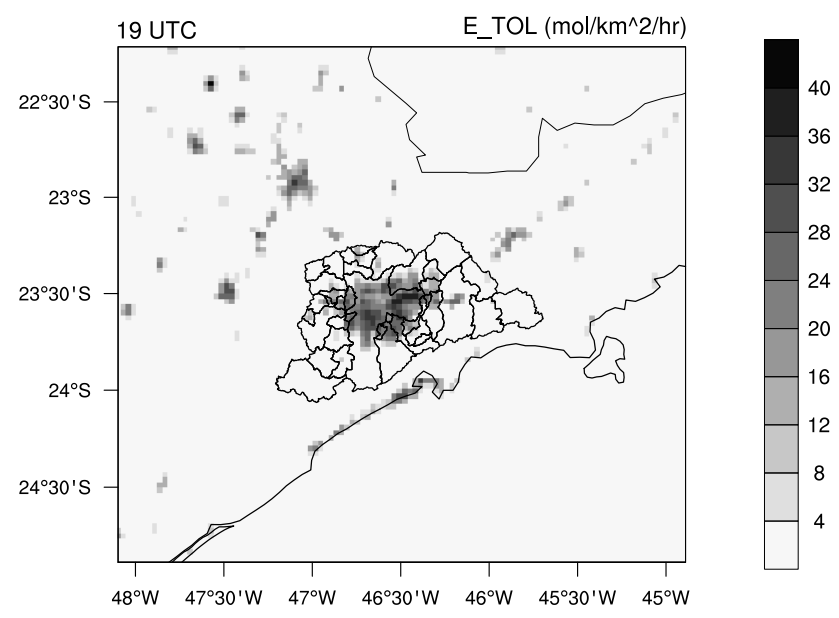

Figure 2. Emission rates for Aromatic VOCs at 19:00 UTC in the $3 \mathrm{~km}$ modelling domain.

Spatial distribution of emissions for the $3 \mathrm{~km}$ modelling domain resolution was based on road density products compiled by the OpenStreetMap project and extracted from the Geofabrik's free download server (http://download. geofabrik.de). Urban areas were assumed to allocate high emissions since these concentrate a road density greater than other areas. In the case of the $15 \mathrm{~km}$ modelling domain, emissions are based on night-time lights data from the Defense Meteorological Satellite Program (http://ngdc.noaa.gov/eog/ dmsp/downloadV4composites.html). These images are 30 arc second grids, spanning from $-180^{\circ}$ to $+180^{\circ}$ longitude and $-65^{\circ}$ to $+75^{\circ}$ latitude and contain the lights from cities, towns and other sites with persistent lighting, including gas flares. Cleaned up night-time light points with no ephemeral events such as forest fires are used to allocate emissions. To estimate the number of vehicles in each grid point of both domains, the sum of individual intensities at each point (i.e. total road length for the $3 \mathrm{~km}$ modelling domain and nighttime light for the $15 \mathrm{~km}$ modelling domain) is firstly normalized by the total fleet, and then distributed uniformly using the total fleet distribution so that emissions in urban areas are mainly represented by emissions coming from their vehicles. Furthermore, due to the complexity involved in describing the temporal variation of emissions at each grid point, median values for vehicular traffic obtained from measurements inside the JQ and RA tunnels (Pérez-Martínez et al., 2014) were used for distributing the emissions during the day in both domains. This approximation followed the approach used by Fast et al. (2006) where emission profiles were calculated from median diurnal variations on weekdays and weekends. We have applied the same constant diurnal cycle at all grid points where emissions have values greater than zero. VOC and PM emission profiles were assumed to be the same as for $\mathrm{CO}$ and $\mathrm{NO}_{x}$ emission profiles since these pollutants are also characteristic tracers of emissions of light-duty and 
heavy-duty vehicles, respectively. Figure 2 shows the maximum hourly emission rates for aromatic VOCs in the $3 \mathrm{~km}$ modelling domain. Anthropogenic emissions were not considered in the $75 \mathrm{~km}$ modelling domain.

The Another Assimilation System for WRF-Chem (AAS4WRF) chemical emissions pre-processor developed by the Latin American Observatory (OLE2; Muñoz et al., 2010,2012 ) was used to scale emission rates on WRF curvilinear coordinates. AAS4WRF is appropriate to write chemical emission rates from both surface and elevated sources in the proper WRF data file format, providing an alternative tailored way to assimilate emissions to WRFChem. The method is explained in the OLE2 Wiki pages in detail (http://www.cmc.org.ve/mediawiki/index.php?title= Calidad_de_Aire).

\subsubsection{Other emissions}

Biogenic emissions are calculated online based on the Guenther scheme (Guenther et al., 1993, 1994). The Guenther biogenic emissions model calculates the emission rates using temperature, photo-synthetically active radiation flux and land-use data as the U.S. Geological Survey (USGS) landuse cover system classification if coupled with the WRF model. However, as indicated in the WRF-Chem emissions guide (http://ruc.noaa.gov/wrf/WG11/Emission_guide.pdf), several key chemical species would have been representing relatively low emission rates because of the limited vegetation types in the simulation, and thus their impacts are anticipated to be much lower than those from vehicular emissions.

Dust and sea salt emissions are calculated online following the works of Ginoux et al. (2001) and Gong (2003), respectively. The calculation of Ginoux et al. (2001) for the uplifting of dust particles is based on the surface wind speed, wetness, and information on soil characteristics. The model then solves the continuity equation including the emission, chemistry, advection, convection, diffusion, dry deposition, and wet deposition of each species. The parameterization of sea salt aerosol source function of Gong (2003) is an extended parameterization of Monahan et al. (1986), which scales the generation of marine aerosols from mechanical disruption of wave crests by the wind and sea surface covered by whitecaps.

\section{Results and discussion}

\subsection{Characterization of meteorological conditions}

In order to study and understand the spatial and temporal variability of atmospheric aerosols, $\mathrm{O}_{3}$, and other pollutants (i.e. $\mathrm{CO}, \mathrm{NO}_{x}$ ) during the study period, it was first necessary to analyse the behaviour of main meteorological systems acting on the atmospheric environment of the SPMA and surrounding areas.

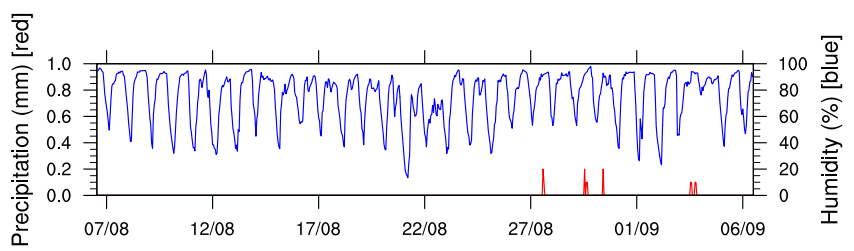

Figure 3. Hourly accumulated precipitation and relative humidity observed at the IAG-USP's climatological station during the study period.

According to the monthly climate reports from the IAGUSP's Climate Research Group (GrEC), the observed precipitation rates were lower than the climatological value in SPMA (anomaly of $-38.6 \mathrm{~mm}$ ) and larger part of the Sao Paulo State during August 2012. Negative anomalies on the precipitation were caused by the intensification of the South Atlantic Subtropical High (SASH). These conditions established an easterly wind anomaly pattern at the $850 \mathrm{hPa}$ level. Conditions were unfavourable for relative humidity coming from the Amazon due to the Low Level Jet (LLJ) and less intense Alisian winds in the Tropical Atlantic (GrEC, 2012a). However, the action of frontal systems favoured the rain accumulation in September 2012, mainly in western Sao Paulo State where the greater positive amount of anomalies were observed. Precipitation events were predominantly observed during the second half of the month. In this case, the wind pattern showed an opposite configuration to that observed in August 2012 as a result of the weakening of the SASH (GrEC, 2012b). The IAG-USP's climatological station recorded an accumulated precipitation of about $1.3 \mathrm{~mm}$ on 3 days of occurrence (28 and 30 August and 4 September 2012) and an easterly wind pattern with a median intensity of $2 \mathrm{~m} \mathrm{~s}^{-1}$ during the period between 7 August and 6 September 2012. Figure 3 shows the hourly accumulated precipitation and relative humidity observed at the IAG-USP's climatological station.

\subsection{Analysis of aerosol species}

Aerosol analysis included species such as organic carbon (OC), elemental carbon (EC), sulphate, nitrate, ammonium, sodium and chloride in addition to other elemental constituent of PM. All the samplings for these species were performed at IAG-USP. Results showed that the major contributors to the concentration of fine particles are OM $(55.7 \%$; OM : OC ratio of 1.5 found by Brito et al., 2013) and EC $(15 \%)$, followed by sulphate $(2.9 \%)$, ammonium $(2.1 \%)$, sodium $(1.9 \%)$, nitrate $(0.5 \%)$, and chloride $(0.3 \%)$. The remaining mass $(21.6 \%)$ is calculated by determining the difference between the total mass of $\mathrm{PM}_{2.5}$ (from the gravimetric analysis) and the sum of the masses of seven individual compounds, as noted above. Part of this remaining mass is related to the water content of aerosols (Andrade et al., 2012). 


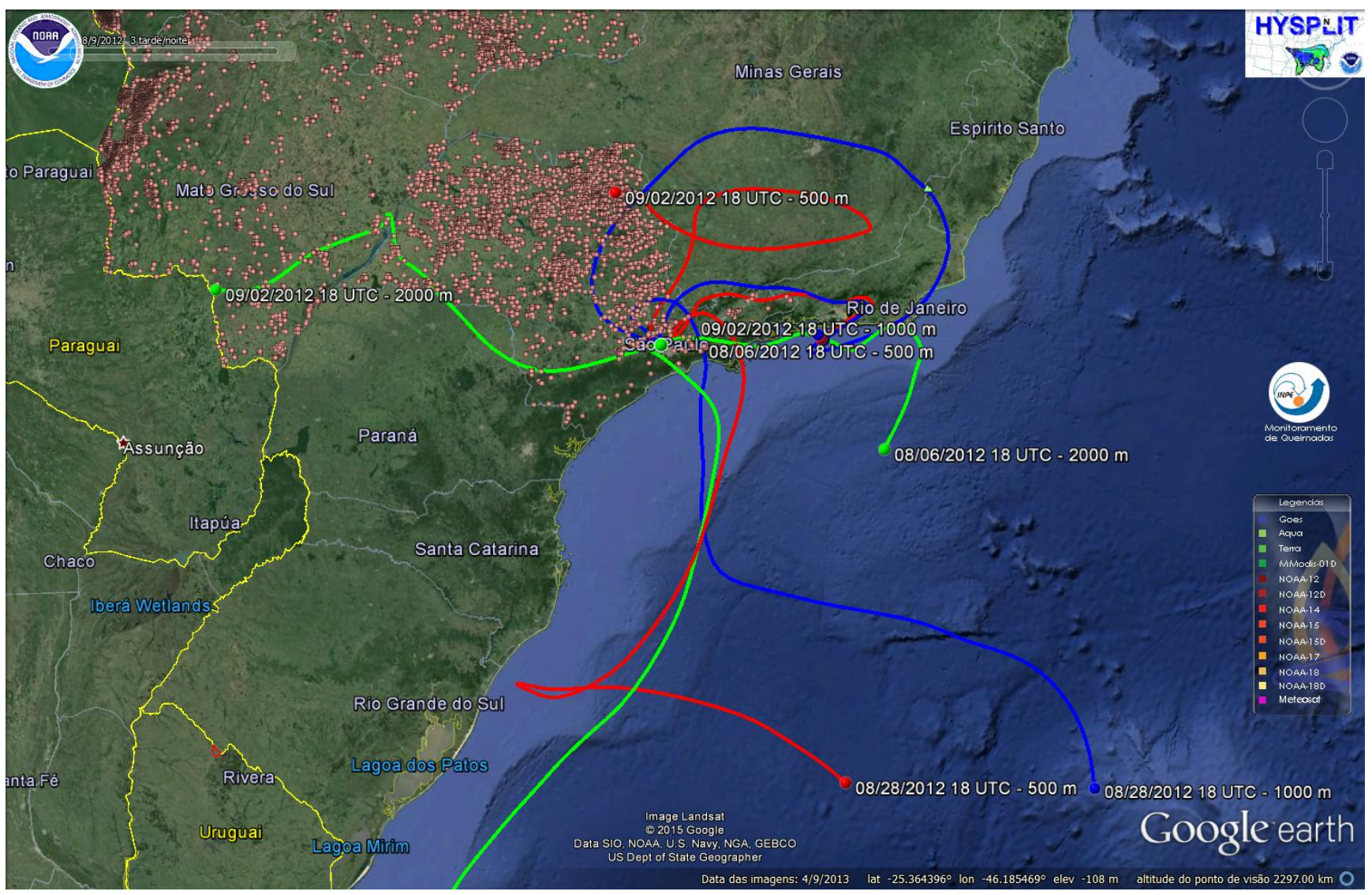

Figure 4. HYSPLIT 3-day backward trajectories and locations of fires in Sao Paulo State and part of central-west region of Brazil. Pink markers represent the observed fire locations during the study period considering different satellite products (GOES, AQUA, TERRA, NOAA). The backward trajectories starting at IAG-USP were calculated for the days 9 and 31 August and 5 September 2012 at three different altitudes: $500 \mathrm{~m}$ (red lines), $1000 \mathrm{~m}$ (blue lines), and $2000 \mathrm{~m}$ (green lines).

On the other hand, $\mathrm{PM}_{2.5}, \mathrm{PM}_{10}$ and size distribution of particles measured at IAG-USP show that the study period was characterized by a reduction in the concentrations up to the end of August 2012 when their minimum values were achieved. This reduction was related to the action of a semistationary front between the coasts of Sao Paulo and Parana States. After the passage of this system, aerosol concentrations have significantly increased what could be related to an increase in relative humidity once the SASH system is moved away from the continent, as well as the transport of aerosol particles produced by forest fires in the central-west region of Brazil and the Sao Paulo State. Several studies have shown the contribution of forest fires on the atmospheric aerosol concentrations in SPMA (Vieira-Filho et al., 2013; Vasconcellos et al., 2010). One way to qualitatively evaluate the contribution of forest fires on aerosol concentrations is by using the air mass trajectories. The Hybrid Single-Particle Lagrangian Integrated Trajectory (HYSPLIT) model (Draxler and Hess, 1998) was used to calculate backward trajectories of air masses in order to identify atmospheric transport of air mass from forest fire areas. Figure 4 shows the 3 -day back- ward trajectories of air masses starting at IAG-USP for the days 9 and 31 August and 5 September, when increases in the OC and EC concentrations were observed at IAG-USP. The pink markers on the map represent the observed fire locations during the study period considering different satellite products (GOES, AQUA, TERRA, NOAA).

Figure 5 shows the concentration of OC, EC and some species of $\mathrm{PM}_{2.5}$ during the study period at IAG-USP. We can observe 11 exceedances of $\mathrm{PM}_{2.5}$ concentration with respect to the air quality standard of $25 \mu \mathrm{g} \mathrm{m}^{-3}$ (see grey line in Fig. 5a) established by the World Health Organization (WHO). These exceedances have mainly occurred at the beginning and at the end of the study period when an increase in the concentrations of OC and EC were observed. The increasing organic matter could be associated to traffic incidents which may raise the emissions, which in case of less favourable meteorological conditions (e.g. lower height of lower planetary boundary layer, PBL, or slow transport of air pollutants) may have led to a more efficient formation of secondary particles. Castanho and Artaxo (2001) analysed the behaviour of the aerosol composition in the SPMA and 

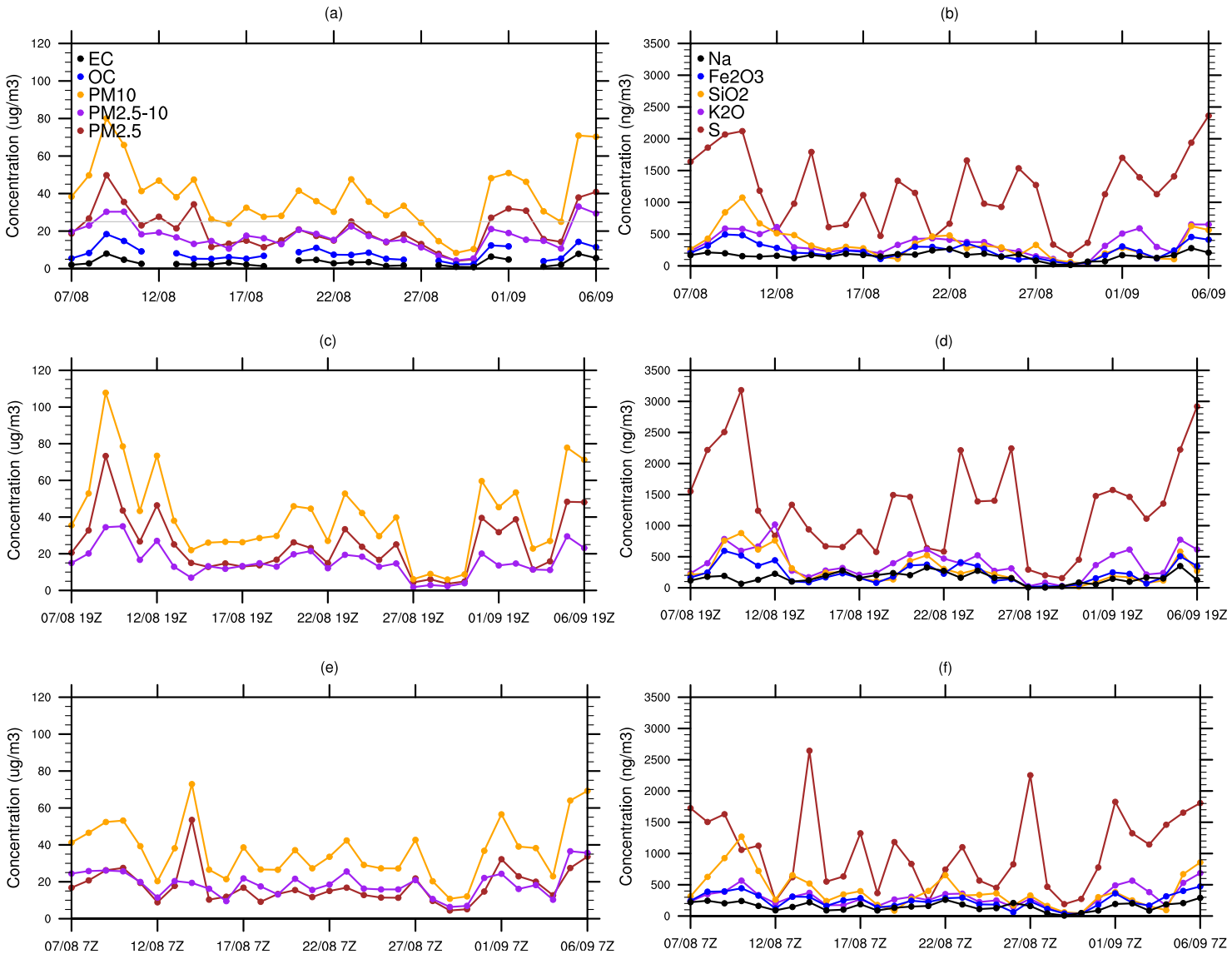

Figure 5. Daily (top), diurnal (bottom), and nocturnal (middle) mean concentrations for EC, OC, $\mathrm{PM}_{10}, \mathrm{PM}_{2.5}-10, \mathrm{PM}_{2.5}$ (left panels), and $\mathrm{Na}, \mathrm{Fe}_{2} \mathrm{SO}_{3}, \mathrm{SiO}_{2}, \mathrm{~K}_{2} \mathrm{O}$, and $\mathrm{S}$ (right panels). The $\mathrm{PM}_{2.5-10}$ aerosol variable is defined as particulate matter with aerodynamic diameter between 2.5 and $10 \mu \mathrm{m}$. The grey line indicates the WHO air quality standard for $\mathrm{PM}_{2.5}\left(25 \mu \mathrm{g} \mathrm{m}^{-3}\right)$.

showed the increase in the concentration of inorganic and organic material in the winter season compared to the summer season, explaining this behaviour with the meteorological characteristics: dry conditions with low height inversion layer in the wintertime and a rainy summer.

Size distributions of aerosol mass indicate that the majority of sulphate, ammonium and $\mathrm{PM}_{10}$ mass concentration is distributed in the size range with diameters between 0.1 and $1 \mu \mathrm{m}$, commonly known as accumulation mode particles (Kumar et al., 2010). In the cases of nitrate, sodium, and chloride, most part of mass was concentrated in particles with diameters greater than $1 \mu \mathrm{m}$.

\subsection{Comparison of baseline simulation with observations}

All the numerical results presented in this section, for the purpose of comparison with the measurements, were obtained from the baseline simulation (Case_0). The predicted temperature, humidity, and $10 \mathrm{~m}$ wind speed and direction have been compared to measurements from the AF-IAG and INT measurement sites. Overall, the model captured the di-

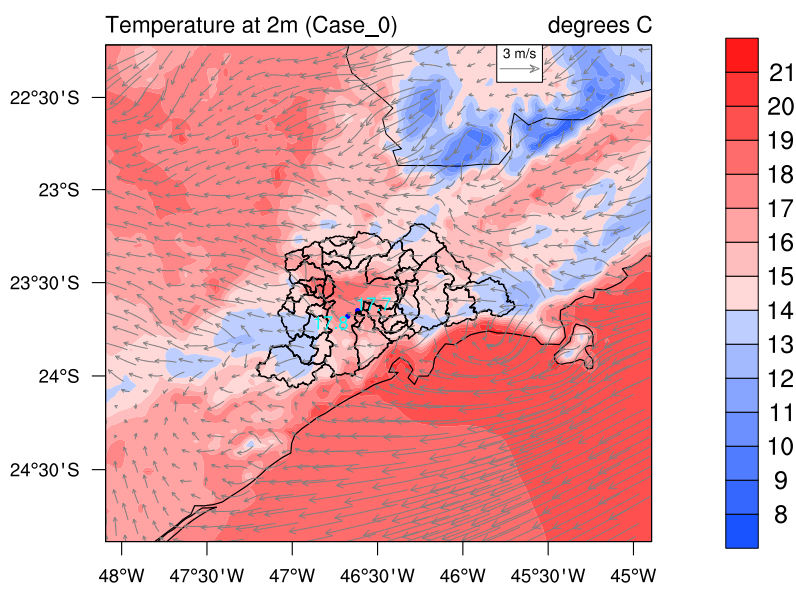

Figure 6. The predicted average of wind vectors at $10 \mathrm{~m}$ and temperature at $2 \mathrm{~m}$ from the baseline simulation (Case_0) for the whole study period in the $3 \mathrm{~km}$ modelling domain. Blue dots represent the locations of the measurement sites, whereas cyan numbers represent the observed average temperature in those sites: $17.7^{\circ} \mathrm{C}$ in AF-IAG and $17.8^{\circ} \mathrm{C}$ in INT. 
Table 5. Performance statistics for WRF-Chem predictions at all sites*.

\begin{tabular}{lrrrrrrrrr}
\hline Index & $\mathrm{PM}_{2.5}$ & $\mathrm{PM}_{10}$ & $\mathrm{O}_{3}$ & $\mathrm{NO}_{x}$ & $\mathrm{CO}$ & $T$ & $\mathrm{RH}$ & $\mathrm{WS}$ & $\mathrm{WD}$ \\
\hline MB & -8.84 & -14.10 & -0.85 & -8.75 & -0.27 & 0.65 & -5.74 & 0.54 & 31.12 \\
MFB (\%) & -47.62 & -38.19 & 22.63 & 12.68 & -32.53 & 1.94 & -7.95 & 41.21 & 31.66 \\
MFE (\%) & 47.90 & 39.90 & 72.85 & 82.82 & 80.93 & 14.16 & 23.84 & 71.12 & 54.40 \\
RMSE$_{U B}$ & 6.83 & 10.59 & 27.45 & 30.35 & 0.57 & 3.21 & 20.06 & 1.08 & 79.38 \\
$R$ & 0.73 & 0.72 & 0.63 & 0.42 & 0.54 & 0.71 & 0.62 & 0.41 & 0.43 \\
\hline
\end{tabular}

* Values are averaged from all the individual indexes found at the measurement sites. Individual indexes are calculated from both hourly observed and predicted values.

urnal variation of temperature, relative humidity, and wind directions reasonably well. However, the predicted wind speeds were higher than the observed values. To evaluate the model performance in solving the meteorology and chemical species, we computed the statistics correlation coefficient $(R)$, mean bias (MB), mean fractional bias (MFB), mean fractional error (MFE), and root mean square error UB $\left(\operatorname{RMSE}_{\mathrm{UB}}\right)$. The definitions of these statistics are given in the Appendix. Figure 6 shows the predicted average of $10 \mathrm{~m}$ wind vectors and $2 \mathrm{~m}$ temperature for the whole study period in the $3 \mathrm{~km}$ modelling domain. Blue dots represent the locations of AF-IAG and INT sites, while the numbers in cyan indicate the observed average temperatures (i.e. $17.7^{\circ} \mathrm{C}$ at AF-IAG and $17.8^{\circ} \mathrm{C}$ at INT). On an average, the predicted wind direction was easterly in SPMA, which has somewhat affected the spatial distribution of aerosol particles as examined later in this section.

Likewise, the statistics used to quantify the model performance in the representation of PM concentration show that, in general, most of prediction-observation pairs present good correlation coefficients, mainly those for $\mathrm{PM}_{10}$, but with negative biases and standard deviations lower than those for observations (see Fig. 10). Table 5 summarizes the performance statistics used in this study showing comparisons between WRF-Chem predictions and observations. The evaluation of WRF-Chem predictions for meteorology and chemical species on a site-by-site basis is presented in the Sects. 1 and 2, respectively, of the Supplement. Figures 7, 8, and 9 show the observed and predicted temporal variations of $\mathrm{PM}_{2.5}, \mathrm{PM}_{10}$, and $\mathrm{O}_{3}$ concentrations at 3, 10 and 6 sites in the SPMA, respectively, with some measurement sites sharing the same grid point for comparisons due to the geographical proximity (e.g. the sites IAG-USP and IPEN-USP both separated around $900 \mathrm{~m}$ from each other).

These figures suggest that predicted concentrations did not present any significant spatial variation in the downtown SPMA and were generally underestimated when compared to measurements. This under prediction could be associated with an underestimation on the vehicular emissions as well as other emission sources (e.g. emissions coming from industry) that are disregarded in this study, in addition to predicted surface winds more intense than those observed, leading to a dilution of aerosol particles in the SPMA. The high concen-
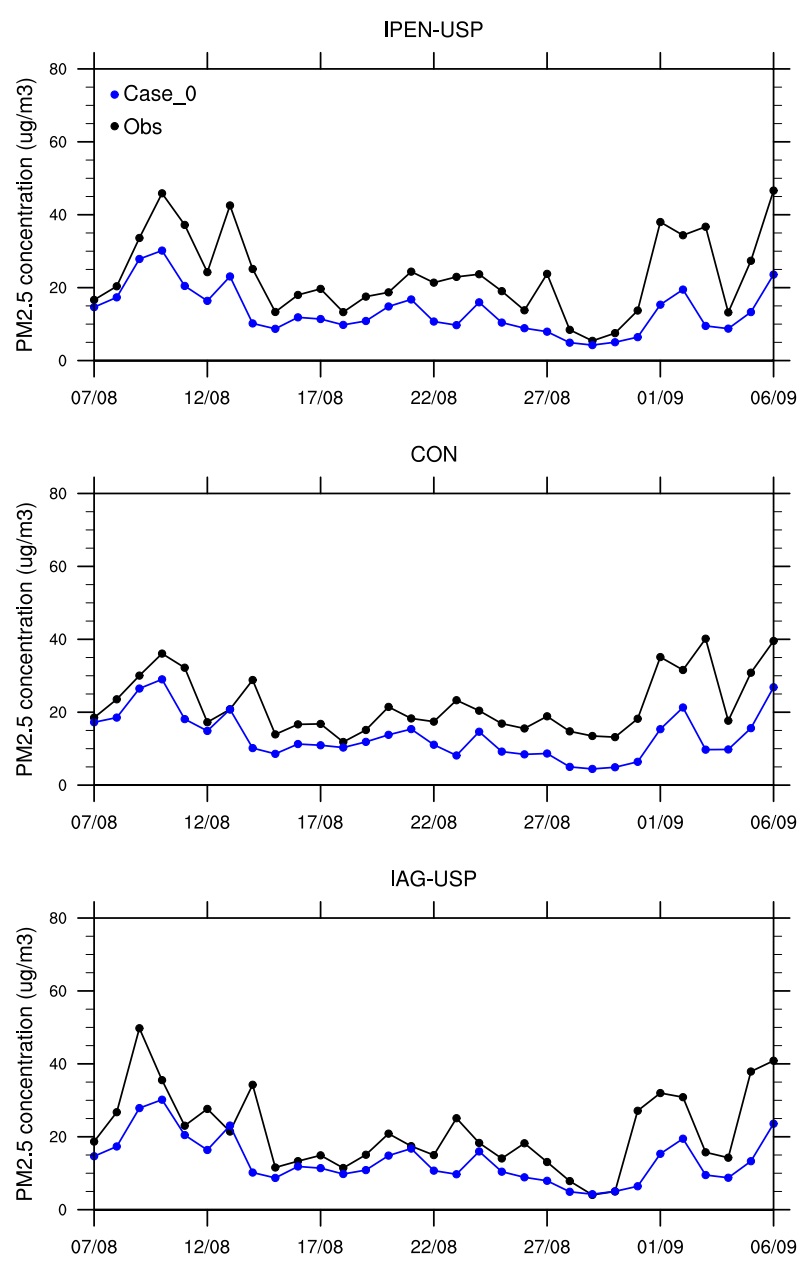

Figure 7. The observed and predicted daily variations of $\mathrm{PM}_{2.5}$ concentrations at three sites in SPMA for the $3 \mathrm{~km}$ modelling domain.

trations of $\mathrm{PM}_{2.5}$ and $\mathrm{PM}_{10}$ observed at the beginning and at the end of the study period, whose variability and trends were reasonably well captured by the model, could be related with the emission of high aerosol loadings due to traffic incidents as well as the establishment of lower PBL heights, commonly observed under post-frontal situations. The results for this simulation (Case_0) show that overall the pre- 

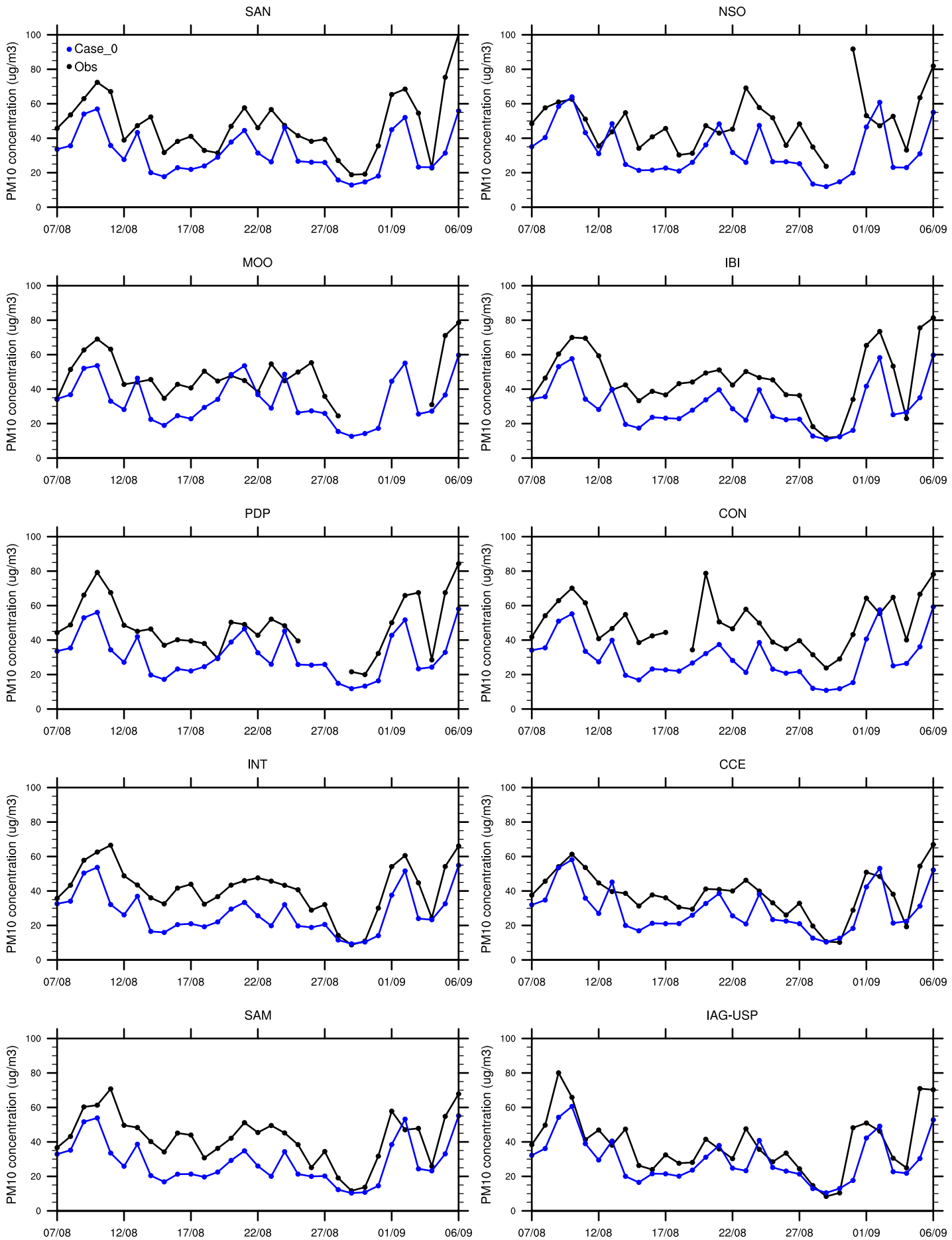

Figure 8. The observed and predicted daily variations of $\mathrm{PM}_{10}$ concentrations at 10 sites in SPMA for the $3 \mathrm{~km}$ modelling domain.

dicted PBL heights (not shown here) have a regular diurnal variation in the downtown SPMA with averaged daily values around $500 \mathrm{~m}$ at both the beginning and the end, and of up to $700 \mathrm{~m}$ in the middle of the study period, when lower concentrations of aerosols were observed.
Figures 11-13 show the predicted average surface distribution of $\mathrm{PM}_{2.5}, \mathrm{PM}_{10}$, and $\mathrm{PM}_{2.5}: \mathrm{PM}_{10}$ ratio for the $3 \mathrm{~km}$ modelling domain, respectively. Red dots and cyan numbers represent the locations and the observed mean PM concentrations (or mean PM concentration ratios) at the measurement sites, respectively. Major contributions of $\mathrm{PM}_{2.5}$ on the to- 

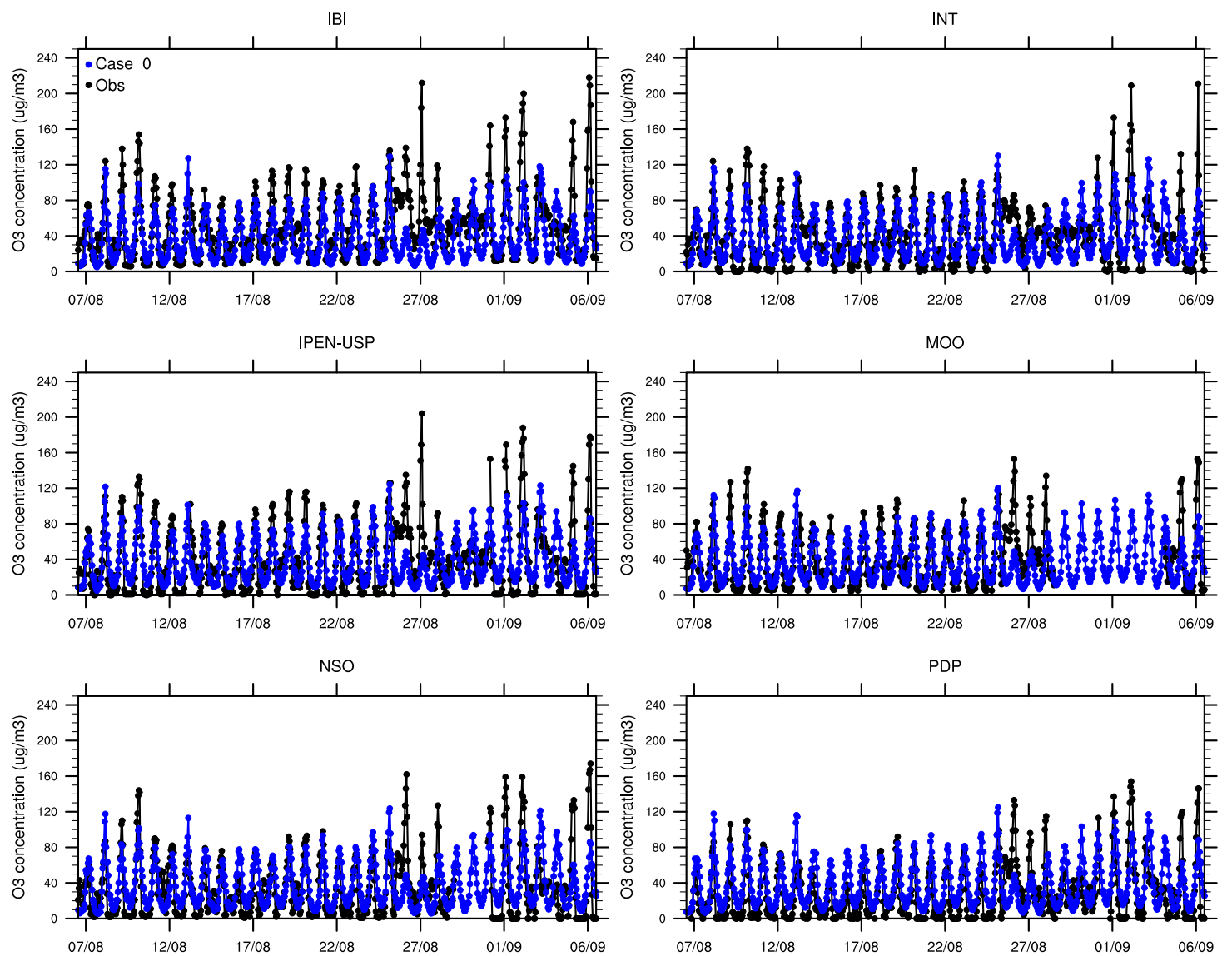

Figure 9. The observed and predicted hourly variations of $\mathrm{O}_{3}$ concentrations at six sites in SPMA for the $3 \mathrm{~km}$ modelling domain.

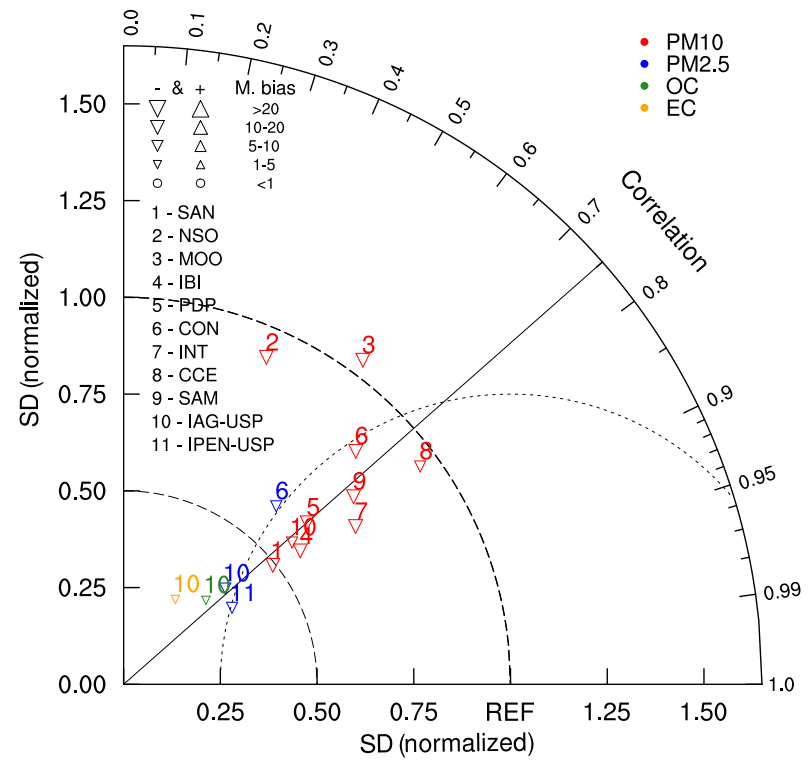

Figure 10. Taylor diagram (Taylor, 2001) showing the individual correlation coefficients, mean biases, and normalized standard deviations for the $\mathrm{PM}_{10}, \mathrm{PM}_{2.5}$, $\mathrm{OC}$, and $\mathrm{EC}$ concentrations. tal $\mathrm{PM}_{10}$ concentration were observed mainly over offshore continental areas (see Fig. 13). High $\mathrm{PM}_{2.5}: \mathrm{PM}_{10}$ concentration ratios would be firstly associated with the transportation of fine particles and gases from upwind regions (see Fig. 6), followed by a production of fine particles from biogenic emissions. Additional comparisons between the observed and predicted concentrations of OC and EC at IAGUSP (the only site with measurements of OC and EC) are shown in Fig. 14. As it has been pointed out in Sect. 2 of the Supplement, under predicted OC concentrations could be associated, among others (e.g., underestimation of POA emissions, inaccurate meteorological predictions), with an underestimation of SOA, probably due to the absence of oxidation of monoterpenes and a limited treatment of anthropogenic VOCs oxidation in the RADM2 mechanism, as discussed by Tuccella et al. (2012). The SORGAM aerosol module considers the formation of anthropogenic SOAs from the oxidation of alkane, alkene, and aromatic VOCs as well as the biogenic SOA formation from the oxidation of alpha-pinene, limonene and isoprene VOCs. Recent studies coupling nontraditional SOA models (volatility basis set approaches) in WRF-Chem show improvements in the predicted SOA concentrations, although these are still lower than those observed 


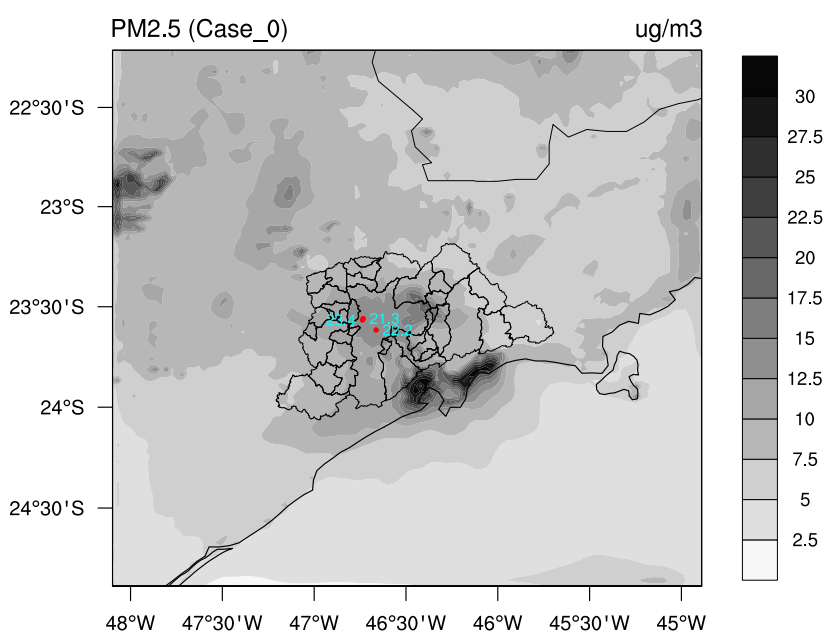

Figure 11. The predicted average surface distribution of $\mathrm{PM}_{2.5}$ concentrations for the whole study period in the $3 \mathrm{~km}$ modelling domain. Red dots represent the locations of the measurement sites with information on $\mathrm{PM}_{2.5}$, whereas cyan numbers represent the observed average $\mathrm{PM}_{2.5}$ concentration in those sites: $23.4 \mu \mathrm{g} \mathrm{m}^{-3}$ in IPEN-USP, $21.3 \mu \mathrm{g} \mathrm{m}^{-3}$ in IAG-USP, and $22.2 \mu \mathrm{g} \mathrm{m}^{-3}$ in CON.

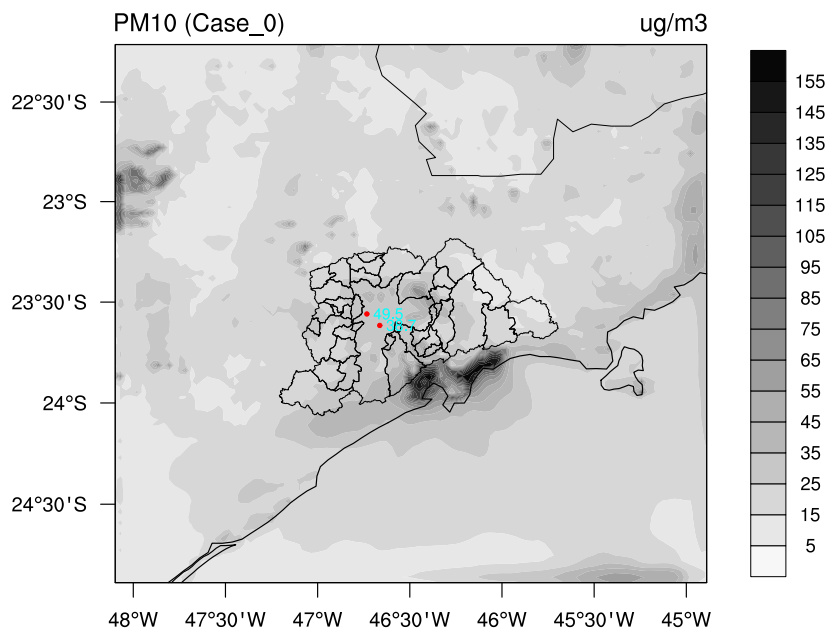

Figure 12. The predicted average surface distribution of $\mathrm{PM}_{10}$ concentrations for the whole study period in the $3 \mathrm{~km}$ modelling domain. Red dots represent the locations of the measurement sites with information on $\mathrm{PM}_{10}$, whereas cyan numbers represent the observed average $\mathrm{PM}_{10}$ concentration in those sites: $49.5 \mu \mathrm{g} \mathrm{m}^{-3}$ in IAG-USP and $38.7 \mu \mathrm{g} \mathrm{m}^{-3}$ in CON.

(e.g. Li et al., 2011b; Ahmadov et al., 2012; Shrivastava et al., 2013).

On the other hand, measurements of mass size distribution were also made with a MOUDI impactor at IAGUSP, following the protocol described in Miranda and Andrade (2005). Constituents of aerosol were subsequently determined by X-Ray fluorescence analysis and ion chromatography analysis. As previously indicated in this section, the main identified species are $\mathrm{SO}_{4}, \mathrm{NO}_{3}, \mathrm{NH}_{4}, \mathrm{Na}$, and $\mathrm{Cl}$. The

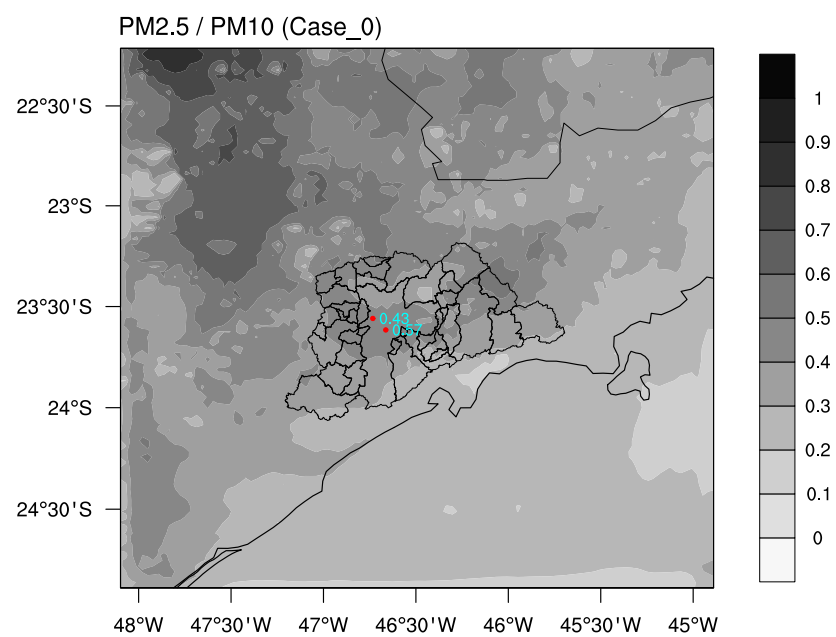

Figure 13. The predicted average surface distribution of the $\mathrm{PM}_{2.5}: \mathrm{PM}_{10}$ ratio for the whole study period in the $3 \mathrm{~km}$ modelling domain. Red dots represent the locations of the measurement sites with information on both $\mathrm{PM}_{2.5}$ and $\mathrm{PM}_{10}$, whereas cyan numbers represent the observed average $\mathrm{PM}_{2.5}: \mathrm{PM}_{10}$ ratio in those sites: 0.43 in IAG-USP and 0.57 in CON.
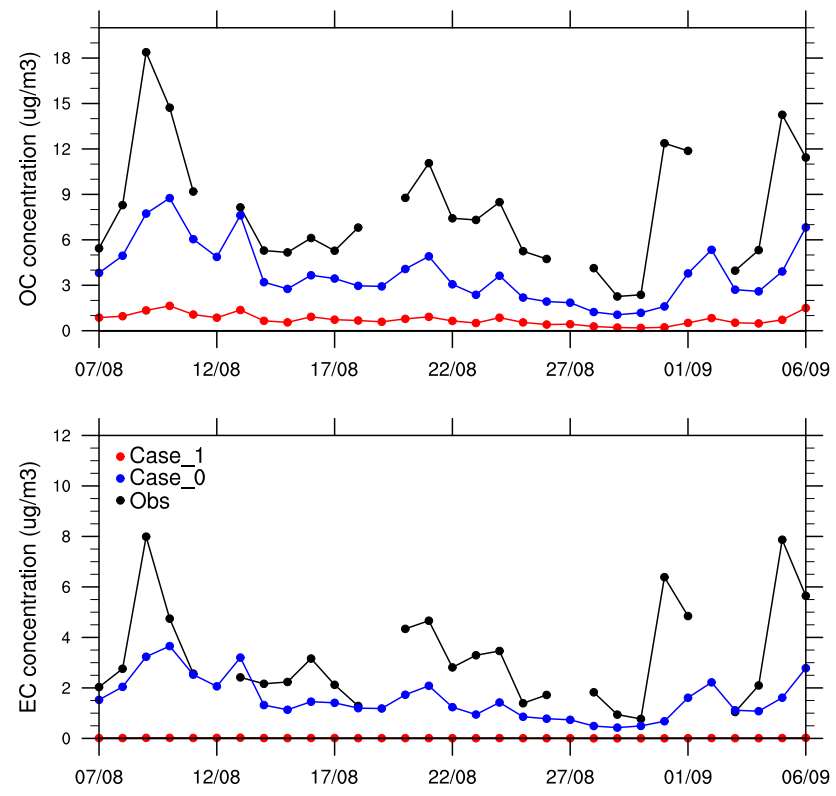

Figure 14. The observed and predicted daily variations of OC and EC concentrations at IAG-USP.

observed average aerosol composition is derived using measurements from both MOUDI impactor and SUNSET analyzer. To perform the comparisons of mass size distribution, we adequately joined the MOUDI bin sizes according to the three modes used by the MADE aerosol module: Aitken $(<0.1 \mu \mathrm{m})$, accumulation $(0.1-1 \mu \mathrm{m})$ and coarse $(>1 \mu \mathrm{m})$. The observed and predicted aerosol mass size distributions averaged over the same sampling time period (16 days along the study period) are shown in Fig. 15. Over the down- 

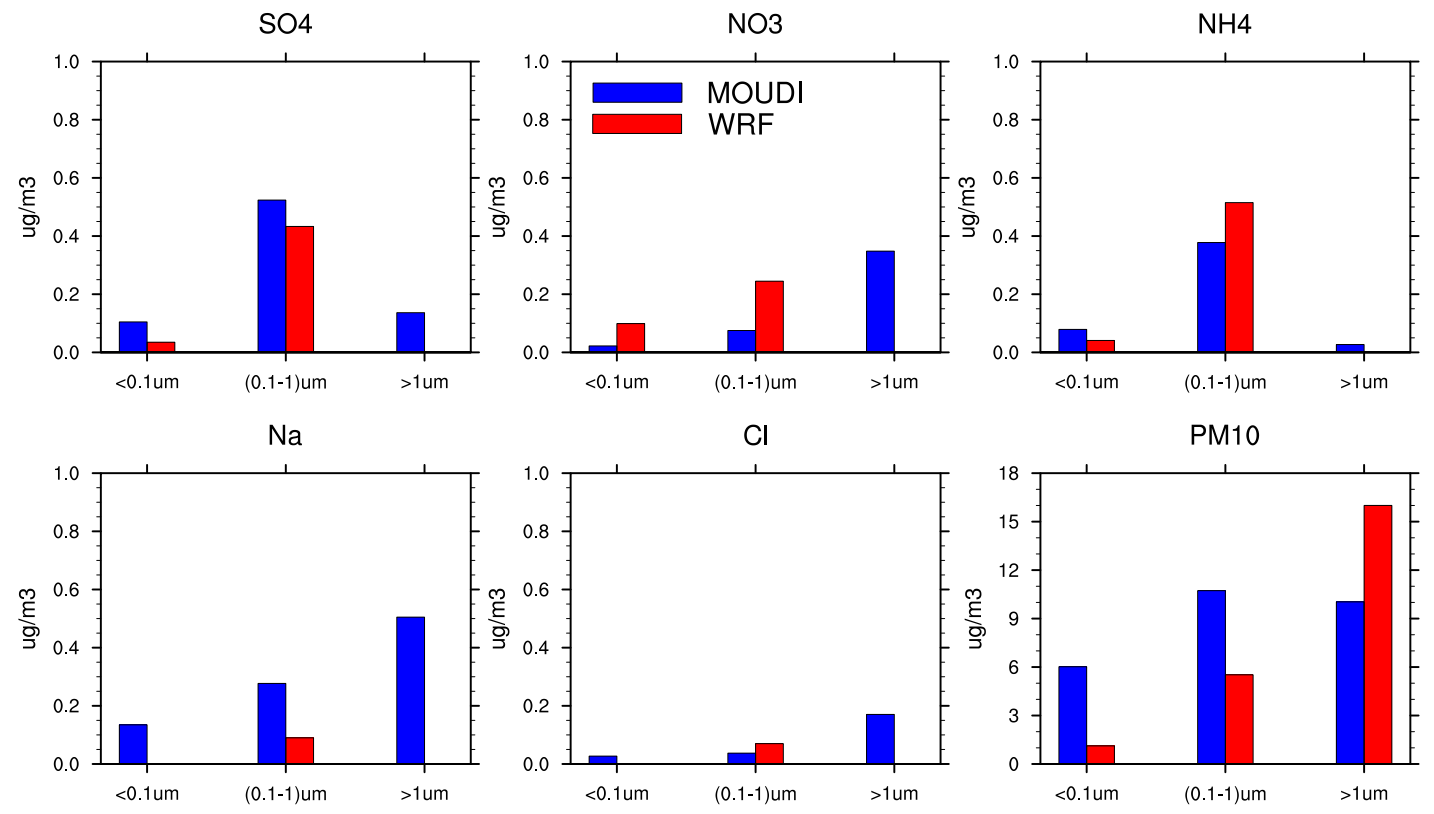

Figure 15. The observed and predicted average aerosol mass size distribution for $\mathrm{SO}_{4}, \mathrm{NO}_{3}, \mathrm{NH}_{4}, \mathrm{Na}, \mathrm{Cl}$, and other $\mathrm{PM} 10$ constituents at IAG-USP. The observed aerosol distributions were collected in 10 size classes using a rotated impactor (MOUDI) and joined adequately according to the three modes used by the MADE aerosol scheme: Aitken $(<0.1 \mu \mathrm{m})$, accumulation $(0.1-1 \mu \mathrm{m})$, and coarse $(>1 \mu \mathrm{m})$. The five inorganic ions carried in MADE are only calculated for the Aitken and accumulation modes. The WRF's PM 10 aerosol variable does not include neither OC nor EC for this comparison.

town SPMA, both the observed and predicted fine particles from accumulation mode account for the majority of the total $\mathrm{PM}_{2.5}$ mass. Since the formation-growth processes of aerosols in question are explicitly treated in the Aitken and accumulation modes, the predicted concentrations for particles larger than $1 \mu \mathrm{m}$ are assumed to be zero. In this case, the mass of particles larger than $1 \mu \mathrm{m}$ is allocated to the $\mathrm{PM}_{10}$ aerosol variable (see Fig. 15). The comparison between the observed and predicted average contributions for the main identified aerosol constituents at IAG-USP is shown in Fig. 16. Both the observed and predicted OC and EC make up the largest fraction of $\mathrm{PM}_{2.5}$ mass with contributions of 55 and $40 \%$, respectively. In addition, it was found that the predicted SOA concentrations contribute $17 \%$ of the predicted total OC concentration at this measurement site. Various global and regional scale SOA simulations have been conducted using mass-based yield and partitioning coefficients, but they have underestimated the SOA concentrations by roughly an order of magnitude, especially over urban regions (Matsui et al., 2014). Using the same SOA formation approach employed by this study and a conversion factor of 1.6 to convert the emissions of OC to OM, Tuccella et al. (2012) found simulated SOA : OM ratios in the 5$40 \%$ range against the observed range of 50-80\%. Although the predicted average $\mathrm{PM}_{2.5}$ concentration $\left(14.48 \mu \mathrm{g} \mathrm{m}^{-3}\right)$ was lower than observed $\left(22.32 \mu \mathrm{g} \mathrm{m}^{-3}\right)$, the mean aerosol chemical composition was reasonably well represented by the model (see Fig. 16).

\subsection{Contribution of dust-sea salt and coarse anthropogenic aerosols to PM concentration}

The evaluation of the contribution of dust and sea salt aerosols on $\mathrm{PM}_{10}$ concentration is performed from the sum of their concentrations divided by the $\mathrm{PM}_{10}$ concentration. The simulated average ratio between dust-sea salt aerosols and the total $\mathrm{PM}_{10}$ mass concentration is shown in Fig. 17b. High concentration ratios have been observed over the ocean where sea salt emissions are by far the most important aerosols source. Unlike high concentration ratios over the ocean, lower concentration ratios are observed over the continent far away from the coast. In this region, the main sources of atmospheric aerosols would be the emission of primary biological aerosol, SOA formed from the emission of biogenic volatile organic compounds (BVOCs), and forest fires. However, particles could also be transported from remote areas. In addition, we can also observe that dust and sea salt aerosols have a contribution between 40 and $50 \%$ of the total $\mathrm{PM}_{10}$ concentration in the downtown SPMA. Furthermore, it is possible to estimate the contribution of all the other $\mathrm{PM}_{10}$ (i.e., the coarse anthropogenic aerosol) to the total $\mathrm{PM}_{10}$ mass concentration. It may be directly calculated from the model or estimated from Figs. 13 and $17 \mathrm{~b}$ once the sum of concentrations of $\mathrm{PM}_{2.5}$, dust and sea salt, and coarse anthropogenic aerosol represents $100 \%$ of the total $\mathrm{PM}_{10}$ mass concentration. For example, we found that the coarse 


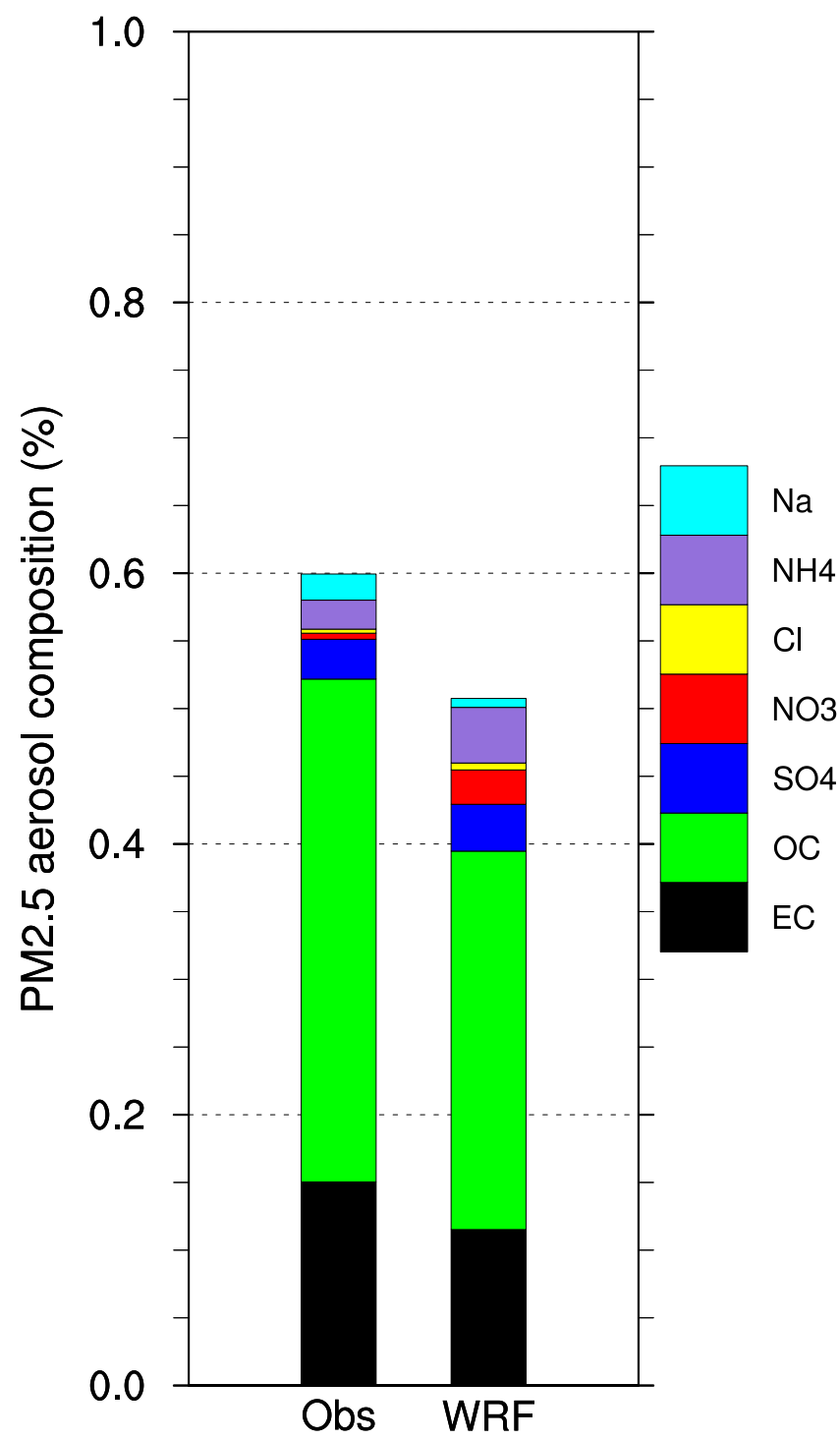

Figure 16. The observed and predicted average contributions for the main identified constituents of $\mathrm{PM}_{2.5}$ at IAG-USP.

anthropogenic aerosol represents around $10 \%$ of $\mathrm{PM}_{10}$ in the downtown SPMA.

\subsection{Evaluation of secondary aerosol formation}

As described in Sect. 2.1, aerosol module employed by this study (MADE/SORGAM) includes the homogeneous nucleation in the sulphuric acid-water system. The sulphuric acid is the most significant condensable molecule formed in the atmosphere, which has also been long recognised as the most important molecule from the point of view of the nucleation of new particles (Jenkin and Clemitshaw, 2000; Seinfeld and Pandis, 2006). However, for the SPMA, the importance of SOA formed from the anthropogenic emission of fuel used by the transport sector was noted (Salvo and Geiger, 2014).
According to the official emission inventory developed by the Sao Paulo Environmental Protection Agency (CETESB, 2013), the SOA explains $51 \%$ of the fine particle mass concentration, with the vehicular emission being its main source. The subsequent growth processes involve aerosol growth by condensation of condensable material onto existing particles, and by coagulation of particles to form larger particles (Kumar et al., 2011, 2014). For example, particles in the accumulation mode emerge through coagulation of particles from the Aitken mode (Kumar et al., 2011). It is important to emphasize that the boundaries were updated with gas and aerosol background concentrations coming from the $15 \mathrm{~km}$ modelling domain during the whole simulation period. Thereafter, the impact of vehicular emissions on the formation of fine particles was calculated from the predicted $\mathrm{PM}_{2.5}$ concentration considering an emission scenario (Case_1) in which only emission of gases from vehicles and vegetation are taken into account to be emitted to the atmosphere from the surface. The predicted average $\mathrm{PM}_{2.5}$ (Case_1): $\mathrm{PM}_{2.5}$ (Case_0) ratio is shown in Fig. 17a. A contribution between 20 and $30 \%$ in the predicted baseline $\mathrm{PM}_{2.5}$ concentration in downtown SPMA is found to correspond to the fine particles formation and transportation processes. Higher concentration ratios over the SPMA surroundings (30-50\%) could be associated with more efficient biogenic emissions. Overall, it is observed that the formation efficiency increases towards the northwest from the ocean. Deep red areas in Fig. 17a could also be associated with the transportation of fine particles and gases from other regions, in addition to having a more efficient production of fine particles from biogenic emissions. For example, given the distribution of winds in Fig. 6, the northern boundary could represent the main source of particles and gases over this part of the simulation domain. Additionally, the comparison between the predicted and observed OC and EC concentrations at IAG-USP shown in Fig. 14 includes the Case_1 simulation in which only emission of primary gases is taken into account in the assessment of fine particles formation. The concentration peaks observed at the beginning and at the end of the study period may be associated with the transport of aerosol particles from both biomass and fossil fuel burning areas (see Fig. 4). Considering the Case_1 simulation, we can observe very low concentrations for EC (mean concentration of $0.01 \mu \mathrm{g} \mathrm{m}^{-3}$ ), as expected. This is because these particles are not produced by photochemical processes in the atmosphere, but associated mainly with the diesel exhaust.

\subsection{Aerosol impact on $\mathrm{O}_{3}$ photochemistry}

Ozone photochemistry production mainly depends on the two key photolysis rates, as shown in Reactions (R1) and (R2), i.e. shortwave radiation able to reach the surface to 

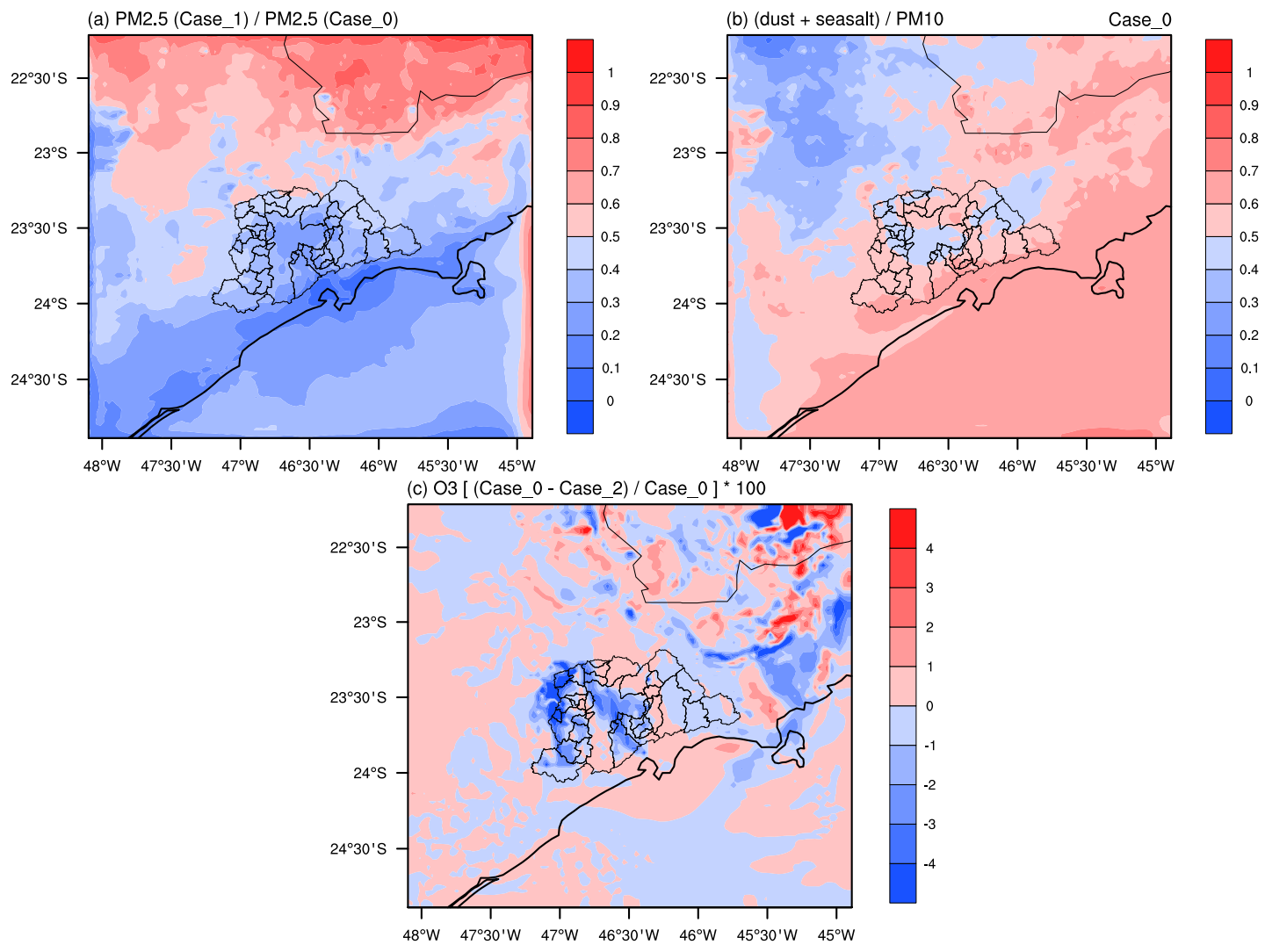

Figure 17. The impact of (a) emissions of primary gases on the fine particles formation, (b) emissions of dust-sea salt aerosols on the $\mathrm{PM}_{10}$ concentration, and (c) aerosol direct effect on the ground level $\mathrm{O}_{3}$ concentrations at 16:00 (local time).

break molecules of $\mathrm{O}_{3}$ and $\mathrm{NO}_{2}$.

$\mathrm{O}_{3}+h v \rightarrow \mathrm{O}_{2}+\mathrm{O}\left({ }^{1} \mathrm{D}\right) \quad(\lambda<320 \mathrm{~nm})$

$\mathrm{NO}_{2}+h v \rightarrow \mathrm{NO}+\mathrm{O}\left({ }^{3} \mathrm{P}\right) \quad(\lambda<420 \mathrm{~nm})$

Therefore, the impact of aerosols on $\mathrm{O}_{3}$ photochemistry has been evaluated from the impact of aerosols on downward shortwave radiation. Attenuation (scattering and absorption) of downward shortwave radiation by aerosols may substantially modify the photolysis rates, and thereby affecting the ozone photochemistry production.

The average percentage change in surface $\mathrm{O}_{3}$ concentrations at 16:00 (local time) with and without the aerosolradiation feedback module turned on are shown Fig. 17c. Overall $\mathrm{O}_{3}$ is destroyed or formed (incoming transport from other regions) in small quantities between -1 and $+1 \%$ in relation to its total concentration. In addition, it was observed that the surface $\mathrm{O}_{3}$ concentration decreased by around $2 \%$ in the downtown SPMA. Li et al. (2011a) found that the impact of aerosols on $\mathrm{O}_{3}$ formation in Mexico City was most pronounced in the morning with the $\mathrm{O}_{3}$ reduction of 5-20\%, but the reduction is less than $5 \%$ in the afternoon. Low reductions in the $\mathrm{O}_{3}$ concentration in the downtown SPMA compared to results from other studies may be explained by the lower predicted $\mathrm{PM}_{10}$ concentrations, which can lead to a minor attenuation of the incoming solar radiation. Simulated mean downward shortwave fluxes at ground surface (not shown) were up to 5\% higher for the Case_2 than for the Case_0 during the afternoon. The inclusion of the direct effect of aerosol particles was found to have small reductions in the surface temperature (changes by around $2 \%$ ), presumably due to an increase in the number of atmospheric processes involving downward longwave fluxes over this area. Forkel et al. (2012) found an underestimation of predicted downward longwave radiation over the southern Baltic Sea when the direct effect of aerosol particles was neglected. Despite the highly non-linear behaviour of tropospheric $\mathrm{O}_{3}$, the reduction in the predicted $\mathrm{O}_{3}$ concentrations indicates a high efficiency of aerosols to attenuate the downward shortwave radiation, what is plausible once it was found that low $\mathrm{PM}_{10}$ concentrations have a capability to reduce ground-level $\mathrm{O}_{3}$ concentrations in a few $\mathrm{ppb}$.

\section{Summary and conclusions}

The WRF-Chem community model has been used to evaluate the impact of vehicular emissions on the fine particles formation in the SPMA. Three 31-day simulations, covering a period from 7 August to 6 September 2012, have been per- 
formed. The aims were to evaluate the impact of fine particles formation (both inorganic and SOA) from gases emitted by road vehicles as well as the aerosol impacts on the ozone formation photochemistry. The results were compared with the measurements available from the NUANCE-SPS project.

The predicted temporal variations of meteorology, $\mathrm{PM}_{2.5}$, $\mathrm{PM}_{10}$, and $\mathrm{O}_{3}$ were found to agree well with the measurements at most of the sites during the entire simulation period. However, the predicted concentrations of $\mathrm{PM}_{2.5}, \mathrm{PM}_{10}$, and $\mathrm{O}_{3}$ (but in minor intensity) were lower than the observed values. This difference could be associated with an underestimation of the vehicular emissions and other emission sources such as industry, heating, and cooking, which are not considered in this study. Wind speed and direction played an important role in the distribution of fine particles over the simulation domain. Backward trajectories analysis suggested that aerosol particles from biomass burning were transported to SPMA, impacting on the PM concentration over this region.

The baseline simulation (Case_0) showed that dust and sea salt aerosols made a contribution between 40 and $50 \%$ of the total $\mathrm{PM}_{10}$ concentration in the downtown SPMA. On the other hand, the Case_1, which represents simulations with gaseous emissions only, indicates that the emissions of primary gases coming mainly from vehicles have a potential to form new particles between 20 and $30 \%$ in relation to the baseline $\mathrm{PM}_{2.5}$ concentration found in the downtown SPMA. Finally, the Case_2, which represents simulations with aerosol-radiation feedback turned on, reveals a reduction in the surface $\mathrm{O}_{3}$ concentration by around $2 \%$ in the afternoon (16:00; local time) when the aerosol-radiation feedback is taken into account.

This study provides a first step to understand the impact of vehicular emissions on the secondary particles formation in the SPMA. Nevertheless, more experimental campaigns are recommended for future work in order to characterize aerosols in ambient air and to improve their emission estimates so that a better understanding of physical and chemical properties and their formation can be established. This study also evaluates the importance of the VOCs in the formation of not only $\mathrm{O}_{3}$ but also of fine particles. These compounds play an important role concerning health impacts and climate change, and the control of their concentrations requires the description of their formation mechanisms. 


\section{Appendix A}

The statistics used in this study are defined as follows:

1. Mean bias (MB)

$$
\mathrm{MB}=\frac{1}{n} \sum_{i=1}^{n}\left(M_{i}-O_{i}\right)
$$

2. Mean fractional bias (MFB)

$$
\mathrm{MFB}=\frac{1}{n} \sum_{i=1}^{n} \frac{2\left(M_{i}-O_{i}\right)}{M_{i}+O_{i}} 100 \%
$$

3. Mean fractional error (MFE)

$$
\mathrm{MFE}=\frac{1}{n} \sum_{i=1}^{n} \frac{2\left|M_{i}-O_{i}\right|}{M_{i}+O_{i}} 100 \%
$$

4. Root mean square error UB $\left(\mathrm{RMSE}_{\mathrm{UB}}\right)$

$$
\mathrm{RMSE}_{\mathrm{UB}}=\sqrt{\frac{1}{n} \sum_{i=1}^{n}\left[\left(M_{i}-\bar{M}\right)-\left(O_{i}-\bar{O}\right)\right]^{2}}
$$

5. Correlation coefficient $(R)$

$$
r=\frac{\sum_{i=1}^{n}\left(M_{i}-\bar{M}\right) \times\left(O_{i}-\bar{O}\right)}{\sqrt{\sum_{i=1}^{n}\left(M_{i}-\bar{M}\right)^{2}} \sqrt{\sum_{i=1}^{n}\left(O_{i}-\bar{O}\right)^{2}}}
$$

where $\bar{O}=\frac{1}{n} \sum_{i=1}^{n} O_{i}$ and $\bar{M}=\frac{1}{n} \sum_{i=1}^{n} M_{i}$ are the average values of the individual observed and predicted values, $O_{i}$ and $M_{i}$, respectively. " $n$ " is the number of observations. 


\section{The Supplement related to this article is available online at doi:10.5194/acp-16-777-2016-supplement.}

Acknowledgements. Prashant Kumar, Angel Vara-Vela and Maria de Fatima Andrade thank the University of Surrey's International Relations Office for the Santander Postgraduate Mobility Award that helped Angel Vara-Vela to visit University of Surrey, UK, and develop this research article collaboratively. The authors from Universities of Surrey and Sao Paulo also acknowledge the collaborative funding received through the University Global Partnership Network (UGPN) to the project titled "Emissions And Role Of Fine Aerosol Particles In Formation Of Clouds and Precipitation (eRAIN) - A demonstration study for the megacity, São Paulo" for supporting this research work. Maria de Fatima Andrade and Angel Vara-Vela acknowledged funding from the Coordination for the Improvement of Higher Education Personnel (CAPES) and Research Foundation of the State of Sao Paulo (FAPESP, project 2008/58104-8) that allowed the experimental campaigns. The authors also thank the WRF-Chem developers, the NOAA's National Geophysical Data Center, the NCAR's Data Support Section and Atmospheric Chemistry Division, the Latin American Observatory (OLE2), the Sao Paulo Environmental Protection Agency (CETESB), the OpenStreetMap Data Extracts, and the NCAR Command Language (NCL) software for providing the tools and datasets used in this research.

Edited by: M. Kanakidou

\section{References}

Ackermann, I. J., Hass, H., Memmesheimer, M., Ebel, A., Binkowski, F. S., and Shankar, U.: Modal aerosol dynamics model for Europe: development and first applications, Atmos. Environ., 32, 2981-2999, 1998.

Ahmadov, R., McKeen, S. A., Robinson, A. L., Bahreini, R., Middlebrook, A. M., de Gouw, J. A., Meagher, J., Hsie, E. Y., Edgerton, E., Shaw, S., and Trainer, M.: A volatility basis set model for summertime secondary organic aerosols over the eastern United States in 2006, J. Geophys. Res., 117, D06301, doi:10.1029/2011JD016831, 2012.

Albuquerque, T. T. A., Andrade, M. F., and Ynoue, R. Y.: Characterization of atmospheric aerosols in the city of Sao Paulo, Brazil: comparisons between polluted and unpolluted periods, Water Air Soil Poll., 195, 201-213, 2011.

Anderson, L.: Ethanol fuel use in Brazil: air quality impacts, Energy Environ. Sci., 2, 1015-1037, 2009.

Andrade, M. F., Fornaro, A., Miranda, R. M., Kerr, A., Oyama, B., Andre, P. A., and Saldiva, P.: Vehicle emissions and $\mathrm{PM}_{2.5}$ mass concentrations in six Brazilian cities, Air Qual. Atmos. Health, 5, 79-88, 2012.

Andrade, M. F., Ynoue, R. Y., Freitas, E. D., Todesco, E., Vara-Vela, A., Ibarra, S., Martins, L. D., Martins, J. A., and Carvalho, V. S. B.: Air quality forecasting system for Southeastern Brazil, Front. Environ. Sci., 3, 1-14, 2015.
Binkowski, F. S. and Shankar, U.: The regional particulate matter model, 1. Mode description and preliminary results, J. Geophys. Res., 100, 26191-26209, 1995.

Birch, M. E. and Cary, R. A.: Elemental carbon-based method for occupational monitoring of particulate diesel exhaust: methodology and exposure issues, Aerosol Sci. Tech., 25, 221-241, 1996.

Brito, J., Rizzo, L. V., Herckes, P., Vasconcellos, P. C., Caumo, S. E. S., Fornaro, A., Ynoue, R. Y., Artaxo, P., and Andrade, M. F.: Physical-chemical characterisation of the particulate matter inside two road tunnels in the São Paulo Metropolitan Area, Atmos. Chem. Phys., 13, 12199-12213, doi:10.5194/acp-1312199-2013, 2013.

Brown, S. G., Lee, T., Roberts, P. T., and Collett Jr., J. L.: Variations in the $\mathrm{OM} / \mathrm{OC}$ ratio of urban organic aerosol next to a major roadway, J. Air Waste Manage., 63, 1422-1433, 2013.

Carvalho, V. S. B., Freitas, E. D., Martins, L. D., Martins, J. A., Mazzoli, C. R., and Andrade, M. F.: Air quality status and trends over the Metropolitan Area of Sao Paulo, Brazil as a result of emission control policies, Environ. Sci. Policy, 47, 68-79, 2015.

Castanho, A. D. A. and Artaxo, P.: Sao Paulo aerosol source apportionment for wintertime and summertime, Atmos. Environ., 35 , 4889-4902, 2001.

CETESB - Companhia de Tecnologia de Saneamento Ambiental: Relatorio Anual de Qualidade do Ar no Estado de Sao Paulo 2009, Sao Paulo, Brazil, 2010.

CETESB - Companhia de Tecnologia de Saneamento Ambiental: Emissões veiculares no Estado de São Paulo 2011, Sao Paulo, Brazil, 2012.

CETESB - Companhia de Tecnologia de Saneamento Ambiental: Relatorio Anual de Qualidade do Ar no Estado de Sao Paulo 2012, Sao Paulo, Brazil, 2013.

Chang, J. S., Binkowki, F. S., Seaman, N. L., McHenry, J. N., Samson, P. J., Stockwell, W. R., Walcek, C. J., Madronich, S., Middleton, P. B., Pleim, J. E., and Lansford, H. H.: The regional acid deposition model and engineering model, State-ofScience/Technology, Report 4, National Acid Precipitation Assessment Program, Washington, DC, USA, 1989.

Costa, R. C. and Sodré, J. R.: Hydrous ethanol vs. gasoline-ethanol blend: Engine performance and emissions, Fuel, 89, 287-293, 2010.

Draxler, R. R. and Hess, G. D.: An overview of the HYSPLIT 4 modelling system of trajectories, dispersion, and deposition, Aust. Meteorol. Mag., 47, 295-308, 1998.

Emmons, L. K., Walters, S., Hess, P. G., Lamarque, J.-F., Pfister, G. G., Fillmore, D., Granier, C., Guenther, A., Kinnison, D., Laepple, T., Orlando, J., Tie, X., Tyndall, G., Wiedinmyer, C., Baughcum, S. L., and Kloster, S.: Description and evaluation of the Model for Ozone and Related chemical Tracers, version 4 (MOZART-4), Geosci. Model Dev., 3, 43-67, doi:10.5194/gmd3-43-2010, 2010.

Fast, J. D., Gustafson, W. I., Easter, R. C., Zaveri, R. A., Barnard, J. C., Chapman, E. G., Grell, G. A., and Peckham, S. E.: Evolution of ozone, particulates, and aerosol direct radiative forcing in the vecinity of Houston using a fully coupled meteorologychemistry-aerosol module, J. Geophys. Res., 111, D21305, doi:10.1029/2005JD006721, 2006.

Forkel, R., Werhahn, J., Hansen, A. B., McKeen, S., Peckham, S., Grell, G., and Suppan, P.: Effect of aerosol-radiation feedback 
on regional air quality - A case study with WRF/Chem, Atmos. Environ., 53, 202-211, 2012.

Ginoux, P., Chin, M., Tegen, I., Prospero, J. M., Holben, B., Dubovik, O., and Lin, S.-J.: Sources and distributions of dust aerosols simulated with the GOCART model, J. Geophys. Res., 106, 20255-20273, 2001.

Gong, S. L.: A parameterization of sea-salt aerosol source function for sub- and super-micron particles, Global Biogeochem. Cy., 17, 1097, doi:10.1029/2003GB002079, 2003.

Gorin, C. A., Collett Jr., J. L., and Herckes, P.: Wood smoke contribution to winter aerosol in Fresno, CA, J. Air Waste Manage., 56, 1584-1590, 2006.

GrEC - Grupo de Estudos Climáticos: Relatório climatológico mensal, previsão climática para o Brasil: Set-Out-Nov/2012, Sao Paulo, Brazil, available at: www.grec.iag.usp.br/link_grec_old/ relatorios_climatologicos/2012/agosto/ (last access: 18 March 2014), 2012a.

GrEC - Grupo de Estudos Climáticos: Relatório climatológico mensal, monitoramento climático para o Brasil: Set/2012, Sao Paulo, Brazil, available at: www.grec.iag.usp.br/link_grec_old/ relatorios_climatologicos/2012/setembro/ (last access: 18 March 2014), 2012b.

Grell, G. A., Peckham, S. E., Schmitz, R., McKeen, S. A., Wilczak, J., and Eder, B.: Fully coupled "online" chemistry within the WRF model, Atmos. Environ., 39, 6957-6975, 2005.

Guenther, A. B., Zimmerman, P. R., Harley, P. C., Monson, R. K., and Fall, R.: Isoprene and monoterpene emission rate variability: model evaluations and sensitivity analyses, J. Geophys. Res., 98D, 12609-12617, 1993.

Guenther, A. B., Zimmerman, P., and Wildermuth, M.: Natural volatile organic compound emission rateestimates for US woodland landscapes, Atmos. Environ., 28, 1197-1210, 1994.

Heal, M. R., Kumar, P., and Harrison, R. M.: Particles, air quality, policy and health, Chem. Soc. Rev., 41, 6606-6630, 2012.

Jenkin, M. E. and Clemitshaw, K. C.: Ozone and other secondary photochemical pollutants: chemical processes governing their formation in the planetary boundary layer, Atmos. Environ., 34, 2499-2527, 2000.

Kroll, J. H. and Seinfeld, J. H.: Chemistry of secondary organic aerosol: Formation and evolution of low-volatility organics in the atmosphere, Atmos. Environ., 42, 3593-3624, 2008.

Kulmala, M., Laaksonen, A., and Pirjola, L.: Parameterization for sulphuric acid/water nucleation rates, J. Geophys. Res., 103, 8301-8307, 1998.

Kumar, P., Robins, A., Vardoulakis, S., and Britter, R.: A review of the characteristics of nanoparticles in the urban atmosphere and the prospects for developing regulatory control, Atmos. Environ., 44, 5035-5052, 2010.

Kumar, P., Ketzel, M., Vardoulakis, S., Pirjola, L., and Britter, R.: Dynamics and dispersion modelling of nanoparticles from road traffic in the urban atmospheric environment - a review, J. Aerosol Sci., 42, 580-603, 2011.

Kumar, P., Morawska, L., Birmili, W., Paasonen, P., Hu, M., Kulmala, M., Harrison, R.M., Norford, L., and Britter, R.: Ultrafine particles in cities, Environ. Int., 66, 1-10, 2014.

Li, G., Zhang, R., and Fan, J.: Impacts of black carbon aerosol on photolysis and ozone, J. Geophys. Res., 110, D23206, doi:10.1029/2005JD005898, 2005.
Li, G., Bei, N., Tie, X., and Molina, L. T.: Aerosol effects on the photochemistry in Mexico City during MCMA2006/MILAGRO campaign, Atmos. Chem. Phys., 11, 51695182, doi:10.5194/acp-11-5169-2011, 2011 a.

Li, G., Zavala, M., Lei, W., Tsimpidi, A. P., Karydis, V. A., Pandis, S. N., Canagaratna, M. R., and Molina, L. T.: Simulations of organic aerosol concentrations in Mexico City using the WRFCHEM model during the MCMA-2006/MILAGRO campaign, Atmos. Chem. Phys., 11, 3789-3809, doi:10.5194/acp-11-37892011, 2011 b.

Marple, V. A., Rubow, K. L., Ananth, G. P., and Fissan, H. J.: MicroOrifice Uniform Deposit Impactor, J. Aerosol Sci., 17, 489-494, 1986.

Martins, L. D., Vasconcellos, P. C., Carvalho, L. F., and Andrade, M. F.: Estimated impact of biogenic hydrocarbon emissions on photochemical oxidant formation in Sao Paulo during two periods of the winters of 1999-2000, Revista Brasileira de Meteorologia, 21, 190-200, 2006.

Matsui, H., Koike, M., Kondo, Y., Takami, A., Fast, J. D., Kanaya, Y., and Takigawa, M.: Volatility basis-set approach simulation of organic aerosol formation in East Asia: implications for anthropogenic-biogenic interaction and controllable amounts, Atmos. Chem. Phys., 14, 9513-9535, doi:10.5194/acp-14-95132014, 2014.

McMurry, P., Shepherd, M., and Vickery, J.: Particulate Matter Science for Policy Makers: A NARSTO Assessment, Cambridge University Press, Cambridge, UK, 2004.

Middleton, P., Stockwell, W. R., and Carter, W. P. L.: Aggregation and analysis of volatile organic compound emissions for regional modelling, Atmos. Environ., 24A, 1107-1133, 1990.

Miranda, R. M. and Andrade, M. F.: Physicochemical characteristics of atmospheric aerosols during winter in the Sao Paulo Metropolitan Area in Brazil, Atmos. Environ., 39, 6188-6193, 2005.

Monahan, E. C., Spiel, D. E., and Davidson, K. L.: A model of marine aerosol generation via whitecaps and wave disruption, in: Oceanic Whitecaps, edited by: Monahan, E. C. and MacNiocaill, G. D., Reidel Publishing Company, Norwell, USA, 167$174,1986$.

Monks, P. S.: Gas-phase radical chemistry in the troposphere, Chem. Soc. Rev., 34, 376-395, 2005.

Muñoz, A. G., López, P., Velásquez, R., Monterrey, L., León, G., Ruiz, F., Recalde, C., Cadena, J., Mejía, R., Paredes, M., Bazo, J., Reyes, C., Carrasco, G., Castellón, Y., Villarroel, C., Quintana, J., and Urdaneta, A.: An Environmental Watch System for the Andean Countries: El Observatorio Andino, B. Am. Meteorol. Soc., 91, 1645-1652, 2010.

Muñoz, A. G., Ruiz-Carrascal, D., Ramírez, P., León, G., Quintana, J., Bonilla, A., Torres, W., Pastén, M., and Sánchez, O.: Risk Management at the Latin American Observatory, in: Risk Management - Current Issues and Challenges, InTech Publications, 533-556, doi:10.5772/50788, 2012.

Nogueira, T., Dominutti, P. A., De Carvalho, L. R. F., Fornaro, A., and Andrade, M. F.: Formaldehyde and acetaldehyde measurements in urban atmosphere impacted by the use of ethanol biofuel: Metropolitan Area of Sao Paulo, 2012-2013, Fuel, 134, 505-513, 2014.

Odum, J. R., Hoffmann, T., Bowman, F., Collins, D., Flagan, R. C., and Seinfeld, J. H.: Gas/particle partitioning and secondary 
organic aerosol yields, Environ. Sci. Technol., 30, 2580-2585, 1996.

Pankow, J. F.: An absorption model of the gas aerosol partitioning involved in the formation of secondary organic aerosol, Atmos. Environ., 28, 185-188, 1994a.

Pankow, J. F.: An absorption model of the gas aerosol partitioning involved in the formation of secondary organic aerosol, Atmos. Environ., 28, 189-193, 1994b.

Pérez-Martínez, P. J., Miranda, R. M., Nogueira, T., Guardani, M. L., Fornaro, A., Ynoue, R., and Andrade, M. F.: Emission factors of air pollutants from vehicles measured inside road tunnels in Sao Paulo: case study comparison, Int. J. Environ. Sci. Technol., 11, 2155-2168, 2014.

Pérez-Martínez, P. J., Andrade, M. F., and Miranda, R. M.: Trafficrelated air quality trends in Sao Paulo, Brazil, J. Geophys. Res. Atmos., 120, 6290-6304, doi:10.1002/2014JD022812, 2015.

Real, E. and Sartelet, K.: Modeling of photolysis rates over Europe: impact on chemical gaseous species and aerosols, Atmos. Chem. Phys., 11, 1711-1727, doi:10.5194/acp-11-1711-2011, 2011.

Salvo, A. and Geiger, F. M.: Reduction in local ozone levels in urban Sao Paulo due to a shift from ethanol to gasoline use, Nat. Geosci., 7, 450-458, doi:10.1038/ngeo2144, 2014.

Saxena, P., Hudischewskyj, A. B., Seigneur, C., and Seinfeld, J. H.: A comparative study of equilibrium approaches to the chemical characterization of secondary aerosols, Atmos. Environ., 20, 1471-1483, 1986.

Schell, B., Ackerman, I. J., Hass, H., Binkowski, F. S., and Ebel, A.: Modelling the formation of secondary organic aerosol within a comprehensive air quality model system, J. Geophys. Res., 106, 28275-28293, 2001.

Seinfeld, J. H. and Pandis, S. N.: Atmospheric Chemistry and Physics: from air pollution to climate change, Second Edition, John Wiley, New Jersey, USA, 2006.
Shrivastava, M., Berg, L. K., Fast, J. F., Easter, R. C., Laskin, A., Chapman, E. G., Gustafson Jr., W. I., Liu, Y., and Berkowitz, C. M.: Modelling aerosols and their interactions with shallow cumuli during the 2007 CHAPS field study, J. Geophys. Res.Atmos., 118, 1343-1360, 2013.

Taylor, K. E.: Summarizing multiple aspects of model performance in a single diagram, J. Geophys. Res., 106, 7183-7192, doi:10.1029/2000JD900719, 2001.

Tuccella, P., Curci, G., Visconti, G., Bessagnet, B., Menut, L., and Park, R. J.: Modelling of gas and aerosol with WRF-Chem over Europe: Evaluation and sensitivity study, J. Geophys. Res., 117, D03303, doi:10.1029/2011JD016302, 2012.

Vasconcellos, P. C., Souza, D. Z., Sanchez-Ccoyllo, O. R., Bustillos, J. O. V., Lee, H., Santos, F. C., Nascimento, K. H., Araujo, M. P., Saarnio, K., Teinila, K., and Hillamo, R.: Determination of anthropogenic and biogenic compounds on atmospheric aerosol collected in urban, biomass burning and forest areas in Sao Paulo, Brazil, Sci. Total Environ., 408, 5836-5844, 2010.

Vieira-Filho, M. S., Pedrotti, J. J., and Fornaro, A.: Contribution of long and mid-range transport on the sodium and potassium concentrations in rainwater samples, Sao Paulo megacity, Brazil, Atmos. Environ., 79, 299-307, 2013.

Wedding, J. B., Weigand, M., John, W., and Wall, S.: Sampling effectiveness of the inlet to the dichotomous sampler, Environ. Sci. Technol., 14, 1367-1370, 1980.

Ynoue, R. Y. and Andrade, M. F.: Size-resolved mass balance of aerosol particles over the Sao Paulo Metropolitan Area of Brazil, Aerosol Sci. Tech., 1, 52-62, 2004. 